\title{
Evidence for use of damage control surgery and damage control interventions in civilian trauma patients: a systematic review
}

Derek J. Roberts ${ }^{1,2^{*}}$ (D, Niklas Bobrovitz ${ }^{3}$, David A. Zygun ${ }^{4}$, Andrew W. Kirkpatrick ${ }^{5,6,7}$, Chad G. Ball ${ }^{5,7,8}$, Peter D. Faris ${ }^{9}$, Henry T. Stelfox ${ }^{6,10,11}$ and for the Indications for Trauma Damage Control Surgery International Study Group

\begin{abstract}
Background: Although damage control (DC) surgery is widely assumed to reduce mortality in critically injured patients, survivors often suffer substantial morbidity, suggesting that it should only be used when indicated. The purpose of this systematic review was to determine which indications for DC have evidence that they are reliable and/or valid (and therefore in which clinical situations evidence supports use of DC or that DC improves outcomes).

Methods: We searched 11 databases (1950-April 1, 2019) for studies that enrolled exclusively civilian trauma patients and reported data on the reliability (consistency of surgical decisions in a given clinical scenario) or content (surgeons would perform DC in that clinical scenario or the indication predicted use of DC in practice), construct (were associated with poor outcomes), or criterion (were associated with improved outcomes when DC was conducted instead of definitive surgery) validity for suggested indications for DC surgery or DC interventions.

Results: Among 34,979 citations identified, we included 36 cohort studies and three cross-sectional surveys in the systematic review. Of the 59 unique indications for DC identified, 10 had evidence of content validity [e.g., a major abdominal vascular injury or a packed red blood cell (PRBC) volume exceeding the critical administration threshold], nine had evidence of construct validity (e.g., unstable patients with combined abdominal vascular and pancreas gunshot injuries or an iliac vessel injury and intraoperative acidosis), and six had evidence of criterion validity (e.g., penetrating trauma patients requiring $>10 \mathrm{U}$ PRBCs with an abdominal vascular and multiple abdominal visceral injuries or intraoperative hypothermia, acidosis, or coagulopathy). No studies evaluated the reliability of indications.

Conclusions: Few indications for DC surgery or DC interventions have evidence supporting that they are reliable and/or valid. DC should be used with respect for the uncertainty regarding its effectiveness, and only in circumstances where definitive surgery cannot be entertained.
\end{abstract}

Keywords: Damage control, Indications, Major trauma, Surgical procedures, operative, Systematic review

\footnotetext{
* Correspondence: Derek.Roberts01@gmail.com

'Division of Vascular and Endovascular Surgery, University of Ottawa, Ottawa,

ON, Canada

${ }^{2}$ Clinical Epidemiology Program, Ottawa Hospital Research Institute, The

Ottawa Hospital, Ottawa, ON, Canada

Full list of author information is available at the end of the article
}

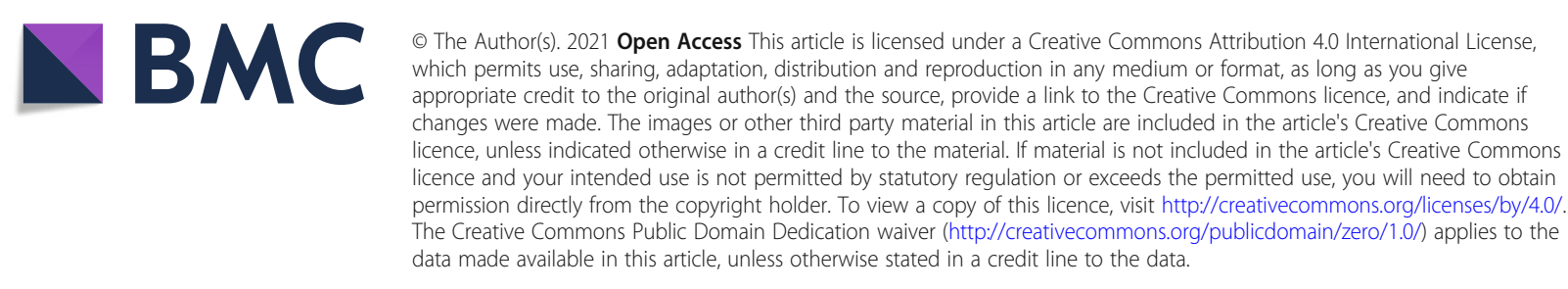




\section{Background}

In patients requiring operative intervention after major trauma, surgeons must decide whether to perform a definitive or damage control (DC) procedure [1, 2]. As opposed to definitive surgery (where all injuries requiring repair are repaired and the explored cavity closed), DC surgery involves quickly controlling exsanguinating hemorrhage and/or gross contamination using one or more abbreviated (or DC) interventions [2]. The patient is subsequently admitted to the intensive care unit (ICU) for ongoing resuscitation with the goal of restoring preinjury physiology before returning to the operating room for additional surgery [2-4].

Although widely assumed to reduce mortality in critically injured patients [5], survivors of DC surgery have been reported to have a high risk of complications (e.g., intra-abdominal sepsis, enteric fistulae, and complex ventral herniae) and often suffer long lengths of ICU and hospital stay [2, 4, 6-11]. It is therefore important to ensure that DC surgery is only performed on patients in which the expected survival benefit of the procedure outweighs its expected risk of negative consequences [1]. Despite this, the benefit/risk profile of using DC surgery in different clinical situations has not been comprehensively evaluated, and several authors have recently reported data suggesting that substantial variation in use of DC surgery exists across trauma centers or that it may be overused [12-15].

We hypothesize that variation in use of DC surgery may be at least partially explained by the uncertainty that exists as to when the procedure is indicated $[1,2]$. Thus, we recently initiated a program of research to develop evidence-informed indications for the appropriate use of DC surgery and DC interventions in civilian trauma patients $[1-3,16-18]$. The purpose of this systematic review and meta-analysis was to determine which indications for DC surgery and DC interventions in civilian trauma patients have evidence supporting that they are reliable and/or valid (and in which clinical situations evidence supports use of DC or that DC improves outcomes). The data reported in this study therefore provide a comprehensive assessment of the reported studies evaluating whether use of DC instead of definitive surgery is associated with improved outcomes in injured patients.

\section{Methods}

\section{Protocol}

Study methods were pre-specified in a protocol developed according to the Preferred Reporting Items in Systematic Reviews and Meta-analyses [19] and Metaanalysis of Observational Studies in Epidemiology [20] statements.

\section{Search strategy}

Using published search strategies designed for identifying indications for DC surgery and DC interventions in trauma patients, we searched MEDLINE, EMBASE, PubMed, Scopus, Web of Science, and the Cochrane Library from their inception to April 1, 2019 without restrictions (see Supplementary Table 1 in our published protocol paper [1] for details of our electronic bibliographic database search strategies). We also used the PubMed "related articles" feature and searched references from included and relevant review articles and abstracts from conferences held between 2009 and 2015, including meetings of the American Association for the Surgery of Trauma (AAST), Australasian Trauma Society, Eastern Association for the Surgery of Trauma (EAST), Trauma Association of Canada, and Western Trauma Association (WTA). To identify unpublished studies, we searched 12 trauma organizational websites [1] and Google Scholar (the first 10 web pages) using combinations of the terms trauma, injury, abbreviated surgery, bailout surgery, damage control, damage control surgery, indication, and predictor.

\section{Study selection}

Two investigators (D.J.R., N.B.) independently screened the titles and abstracts of citations identified by the search and selected articles for full-text review. We included full-text studies that reported original data on the reliability or validity of suggested indications for DC surgery or DC interventions in civilian trauma patients. We excluded studies that included only patients injured in combat or by thermal mechanisms or focused exclusively on DC for emergency general or vascular surgery or orthopedic or neurologic injuries. Study eligibility disagreements were resolved by consensus between the two investigators.

\section{Definitions}

An indication was defined as a clinical finding/circumstance or scenario that reportedly advised use of DC surgery (or a DC intervention) over definitive surgery (or a definitive surgical intervention) [1]. DC surgery was broadly defined as a multi-step operative intervention, which included an abbreviated initial surgical procedure that aimed to rapidly control bleeding and/or gross contamination [1]. We did not predefine DC interventions. Instead, we included articles that satisfied the above criteria where an indication was reported for a surgical intervention suggested by authors to constitute DC or an abbreviated surgical technique [e.g., temporary abdominal closure (TAC)/open abdominal management after trauma laparotomy] [1,2].

Indication reliability was defined as the degree to which the same decision to conduct DC was made when 
surgeons were provided the same clinical finding/scenario (test-retest) or when encountered by the same surgeon (intra-rater) or different surgeons (inter-rater). Validity included content, construct, and criterion validity (see Table 1 for detailed definitions of these measures) $[21,22]$. Content validity was defined as the extent to which surgeons reported that they would perform DC in a given clinical scenario or that an indication predicted use of DC in practice [21,22]. Construct validity referred to how well one indication or a combination of indications and demographic variables predicted poor outcomes in patients not treated with DC (i.e., the extent to which an indication was associated with a higher probability of poor outcomes in patients treated with definitive surgery and therefore should be considered as a potential indication for DC) [21, 22]. Criterion validity referred to the extent to which the utilization or conduct of DC instead of definitive surgery for one or more indications was associated with improved patient outcomes $[21,22]$.

\section{Data extraction}

Two investigators (D.J.R., N.B.) independently extracted data from included studies into pilot-tested tables summarizing characteristics of the included studies and the content, construct, and criterion validity of suggested indications for DC surgery and DC interventions (Table 1). An interpreter assisted with data extraction for one Russian [23] and two Mandarin Chinese [24, 25] language studies. We extracted data on (1) study design, setting, and participants; (2) suggested indications for DC surgery or DC interventions as reported by study authors; and (3) measures of indication reliability and validity. For content validity, we extracted data on the percentage of surgeons that reported that they would perform DC in a given clinical scenario or odds ratios (ORs) or hazard ratios (HRs) [with surrounding 95\% confidence intervals (CIs)] indicating the degree to which that indication predicted use of DC in practice. For construct validity, we extracted data on how well one indication or a combination of indications predicted outcomes in patients not treated with DC. Finally, for criterion validity, we extracted data on the extent to which the utilization or conduct of DC instead of definitive surgery for one or more indications was associated with patient outcomes. Outcomes of interest for the assessment of construct and criterion validity included survival, development of coagulopathy, reported measures of morbidity, and lengths of hospital and ICU stay. Outcomes were extracted at the longest follow-up duration. When both unadjusted and adjusted outcome estimates were reported, the most adjusted estimate was extracted.

\section{Risk of bias assessment}

The same two investigators independently evaluated study risk of bias. Cohort studies were assessed using an expanded version of the Quality in Prognosis Studies

Table 1 Definitions of indications for use of damage control content, construct, and criterion validity

\begin{tabular}{|c|c|c|c|}
\hline $\begin{array}{l}\text { Type of } \\
\text { measurement } \\
\text { validity }\end{array}$ & Epidemiologic definition [21 22] & Operationalized definition & $\begin{array}{l}\text { Theoretical example of study } \\
\text { evaluating indication content, } \\
\text { construct, or criterion validity }\end{array}$ \\
\hline Content & $\begin{array}{l}\text { Extent to which the indication } \\
\text { incorporates the domain of the } \\
\text { phenomenon under study (e.g., the extent } \\
\text { to which the indication includes clinical } \\
\text { situations that surgeons feel may } \\
\text { influence use of DC or that is associated } \\
\text { with the choice to perform DC over } \\
\text { definitive surgery) }\end{array}$ & $\begin{array}{l}\text { Extent to which surgeons reported that } \\
\text { they would perform DC in a given clinical } \\
\text { scenario or that an indication predicted } \\
\text { use of DC in practice }\end{array}$ & $\begin{array}{l}\text { In a cross-sectional survey of surgeons, X\% } \\
\text { reported that they would perform DC } \\
\text { when a major abdominal vascular injury } \\
\text { was identified at laparotomy } \\
\text { In a cohort study, the intraoperative } \\
\text { identification of a major abdominal } \\
\text { vascular injury was associated with OR of } \\
\text { X }(95 \% \mathrm{Cl}, \mathrm{X}-\mathrm{X}) \text { for performing DC instead } \\
\text { of definitive surgery in practice }\end{array}$ \\
\hline Construct & $\begin{array}{l}\text { Extent to which the indication } \\
\text { corresponds to theoretical concepts } \\
\text { (constructs) under study (e.g., if an } \\
\text { indication has construct validity, it should } \\
\text { be associated with poor patient outcomes } \\
\text { when patients undergo definitive instead } \\
\text { of DC surgery) }\end{array}$ & $\begin{array}{l}\text { How well one indication or a combination } \\
\text { of indications and demographic variables } \\
\text { predicted poor outcomes in patients not } \\
\text { treated with DC (i.e., the extent to which } \\
\text { an indication was associated with a higher } \\
\text { probability of poor outcomes in patients } \\
\text { treated with definitive surgery and } \\
\text { therefore should be considered as a } \\
\text { potential indication for DC) }\end{array}$ & $\begin{array}{l}\text { In a cohort study, the intraoperative } \\
\text { identification of a major abdominal } \\
\text { vascular injury was associated with an } \\
\text { increased risk of mortality in patients who } \\
\text { underwent definitive laparotomy for } \\
\text { trauma }\end{array}$ \\
\hline Criterion & $\begin{array}{l}\text { Extent to which the indication related to a } \\
\text { reference standard (e.g., the extent to } \\
\text { which conducting DC instead of definitive } \\
\text { surgery in that clinical situation was } \\
\text { associated with an improvement in } \\
\text { outcomes) }\end{array}$ & $\begin{array}{l}\text { Extent to which the utilization or conduct } \\
\text { of DC instead of definitive surgery for one } \\
\text { or more indications was associated with } \\
\text { improved patient outcomes }\end{array}$ & $\begin{array}{l}\text { In a cohort study, use of DC instead of } \\
\text { definitive surgery for patients with a major } \\
\text { abdominal vascular injury was associated } \\
\text { with an improvement in in-hospital ad- } \\
\text { justed mortality }\end{array}$ \\
\hline
\end{tabular}


tool [26, 27], which included questions regarding study participation and attrition; indication or outcome description and measurement; confounding measurement and account; whether the operative profile chosen (i.e., DC versus definitive surgery) may have varied in relation to the indication of interest; and methods and reporting of statistical analyses (see Supplemental Digital Content 1 for the operationalized list of quality domains evaluated) [2628]. For cross-sectional studies, we evaluated sampling methods, response rates, and whether the reported methods would permit replication; sample was representative of the population; questionnaire was adequately described, pretested, and had evidence of reliability and/or validity; statistical methods; and if all respondents were accounted for [29]. The assessment of statistical analyses incorporated recommendations for appraising logistic regression models [30, 31]. Disagreements regarding risk of bias assessments were resolved by consensus.

\section{Data synthesis}

We used directed qualitative content analysis to group unique indications into the subcategories and categories of a previously developed framework for conceptualizing indications for DC $[3,32]$. We then used a vote counting scale [33] to incorporate our risk of bias assessments into the synthesis of evidence regarding whether indications were reliable and/or valid [26]. The aggregate scale summarized strength of evidence as (1) not reported, (2) inconclusive (no evidence or a low to moderate association in the setting of an overall high amount of bias in at least one quality domain), (3) a consistently strong association in the setting of an overall high amount of bias in only one quality domain, (4) a consistently low to moderate association in the setting of an overall moderate amount of bias in one or more quality domains, (5) a consistently low to moderate association with a low amount of bias in all quality domains or a consistently strong association with an overall moderate amount of bias in one or more study quality domains, and (6) a consistently strong association with a low overall amount of bias in all study domains.

\section{Statistical analyses}

Inter-investigator agreement regarding full-text article inclusion was quantified using kappa ( $\mathrm{k}$ ) statistics [34]. We summarized dichotomous data using counts (percentages) and compared them using ORs with 95\% CIs or Fisher's exact tests. We combined adjusted ORs for indications with similar definitions using MantelHaenszel-weighted DerSimonian and Laird randomeffects models [35]. Heterogeneity in these estimates were assessed using $I^{2}$ statistics and tests of homogeneity $[36,37]$. We considered two-sided $p$ values $<0.05$ statistically significant. Stata MP version 13.1 (Stata Corp., College Station, TX) was used for statistical analyses.

\section{Results}

\section{Study selection}

Among 34,979 citations identified by the search, we included 36 cohort studies $(n=8160$ total trauma patients) $[14,15,23,25,38-68]$ and three cross-sectional surveys ( $n=481$ total surgeon respondents) [69-72] in the systematic review (Fig. 1). Agreement between investigators on full-text article inclusion was excellent ( $\mathrm{\kappa}-$ statistic, $0.72 ; 95 \% \mathrm{CI}, 0.60$ to 0.83 ).

\section{Description of included studies}

Characteristics of included cohort and cross-sectional studies are presented in Table 2 and Supplemental Digital Content 2, respectively. In total, $67 \%$ of the cohort studies were published on or after the year 2000 and $91.7 \%$ were conducted in single centers and $66.7 \%$ in the USA. Five (13.9\%) cohort studies collected data prospectively. Studies describing age and Injury Severity Scale (ISS) scores reported enrolling severely injured (mean/median ISS score range, 17.8-41) young adults (mean/median age range, 26-51.9 years).

The three cross-sectional studies described results of two surveys of AAST members (administered in 19971998 [72] and 2005 [69]) and one of Trauma Association of Canada surgeon members (administered in 2004; results of which were reported across two publications) [70, 71]. Surgeon response rates varied from 26\% [69] to $84 \%[70,71]$. Of the respondents, two studies reported that $73-85 \%$ practiced in academic centers $[69,72]$ and one that $45 \%$ specialized in trauma and critical care [69].

\section{Risk of bias assessment}

The risk of bias assessment for the 36 included cohort studies is outlined in Supplemental Digital File 3. Nine (25.0\%) studies were at high risk of study participation bias, 17 (47.2\%) reported outcome comparisons at high risk of confounding, and $28(77.8 \%)$ did not report follow-up duration. Six of the nine studies at high risk of study participation bias evaluated the construct validity of indications among patients treated only with DC surgery (and therefore outcomes associated with these variables are better interpreted as predictors of poor outcome after DC surgery rather than measures of indication construct validity) $[47,48,56,61,63,66]$. Of the 17 cohort studies that adjusted estimates using logistic regression, these analyses were at a moderate risk of bias in 12 studies and a high risk of bias in one study, largely because of a low or unclear number of events per variable and inadequate reporting of methods used to select predictor variables and/or build models (Supplemental Digital Content 4).

The risk of bias assessment for the three included cross-sectional studies is included in Supplemental Digital File 5. Two studies described methods that would 


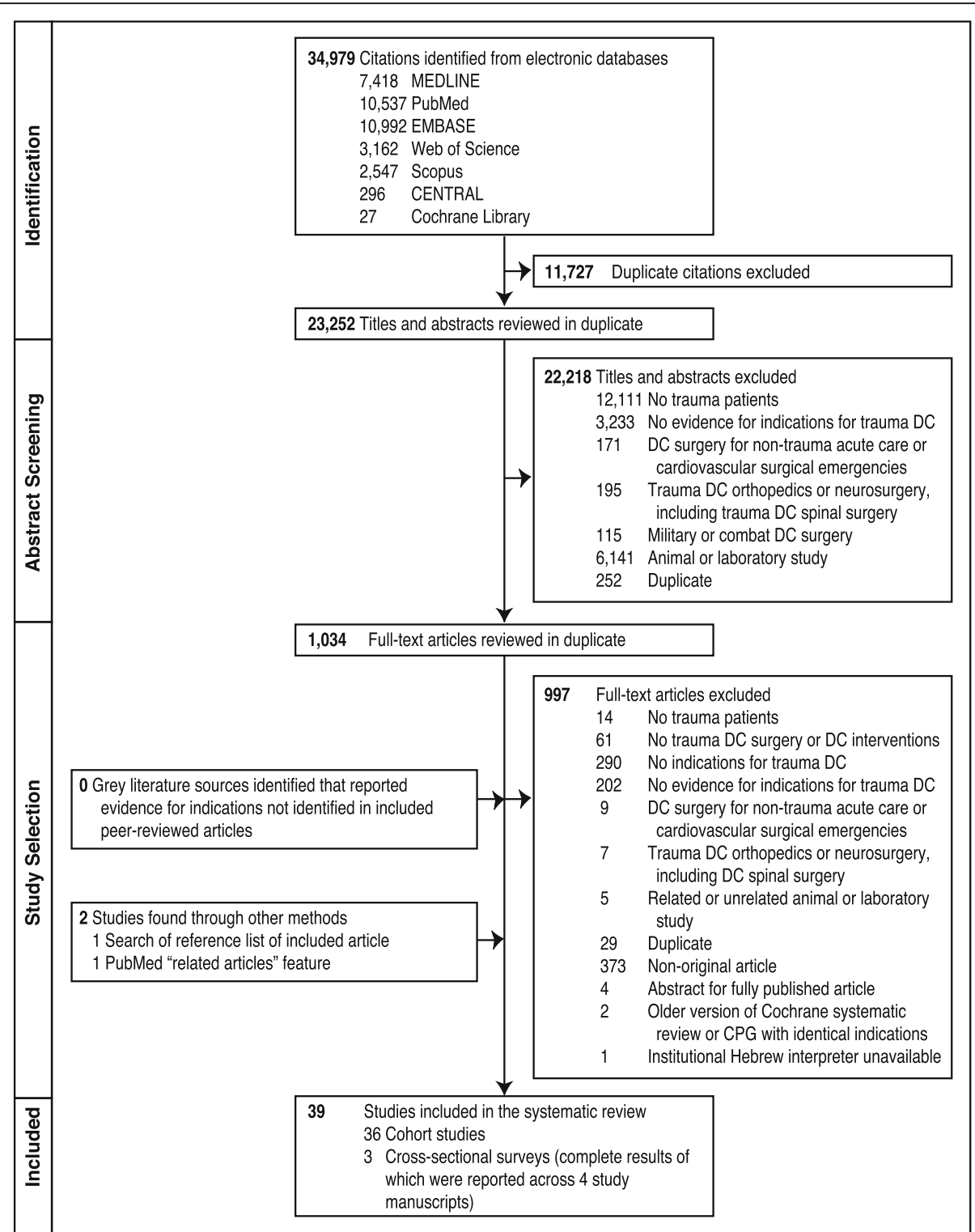

Fig. 1 Flow of articles through the systematic review. Where CPG indicates clinical practice guideline and DC, damage control

permit replication, identified a sample that was likely representative of the broader trauma surgical community, and adequately described the questionnaire (or provided it as supplementary material) [70-72]; however, only one reported that the questionnaire was pretested $[70,71]$ and none provided evidence of questionnaire reliability or validity.

\section{Reliability and validity of indications for use of DC surgery and DC interventions}

The 39 included studies assessed the content, construct, and criterion validity of 116 indications for DC surgery (median per article, 3; range, 1-7) and 32 indications for TAC/open abdominal management (median per article,
7; range, 1-12). No studies evaluated the reliability of indications for DC surgery or DC interventions.

\section{Content validity}

The cross-sectional studies [69-72] evaluated the content validity of indications for TAC after trauma laparotomy by asking surgeons whether open abdominal management was indicated in different clinical situations (see Table 3 for assessments of content validity in crosssectional and cohort studies). Most respondents supported use of TAC when they were unable to close the fascia (or closure was subjectively tight), there was massive visceral edema, planned reoperation was required (e.g., to remove packs or perform a "re-look" 
Roberts et al. World Journal of Emergency Surgery

(2021) $16: 10$

Page 6 of 23

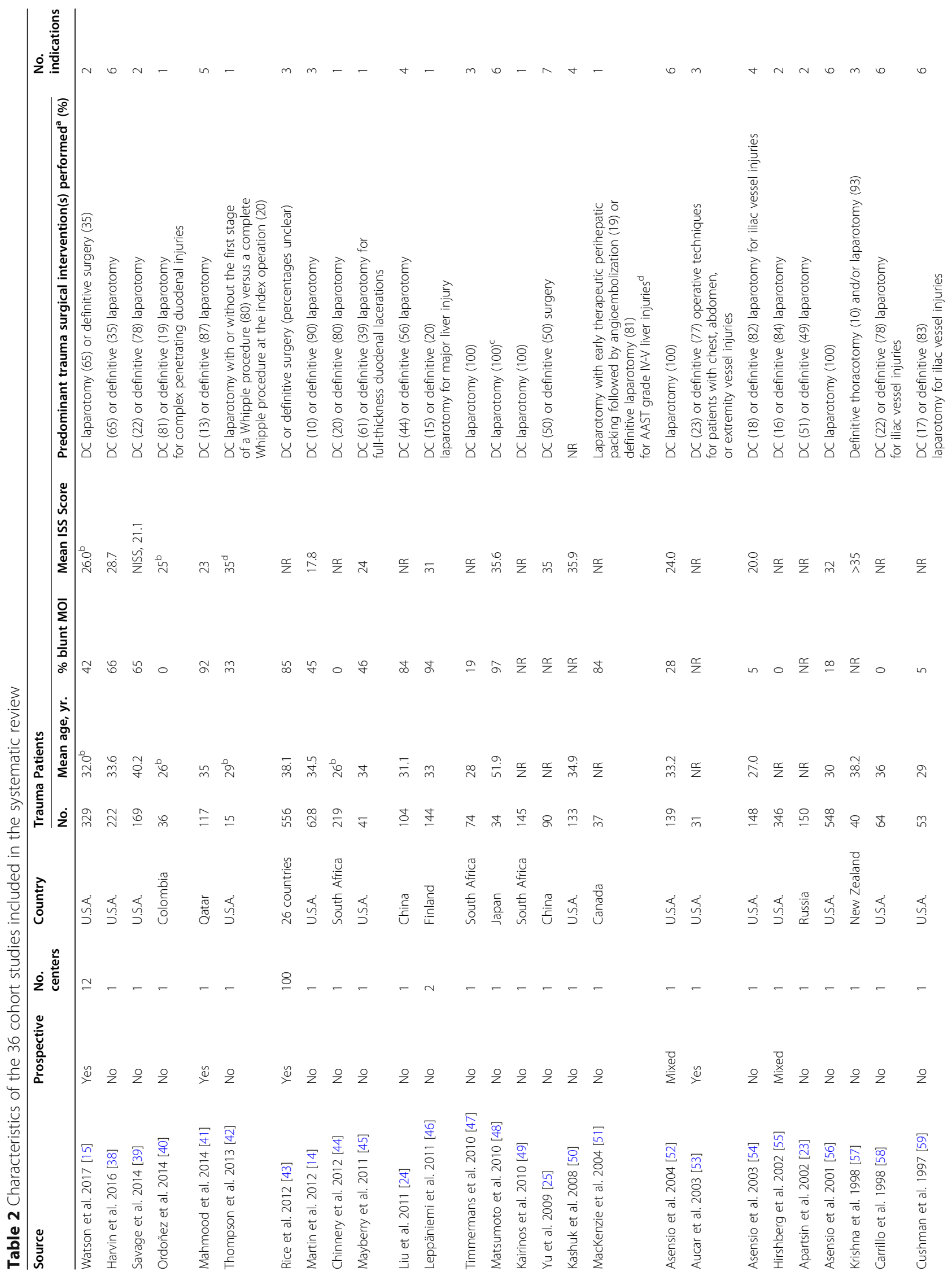




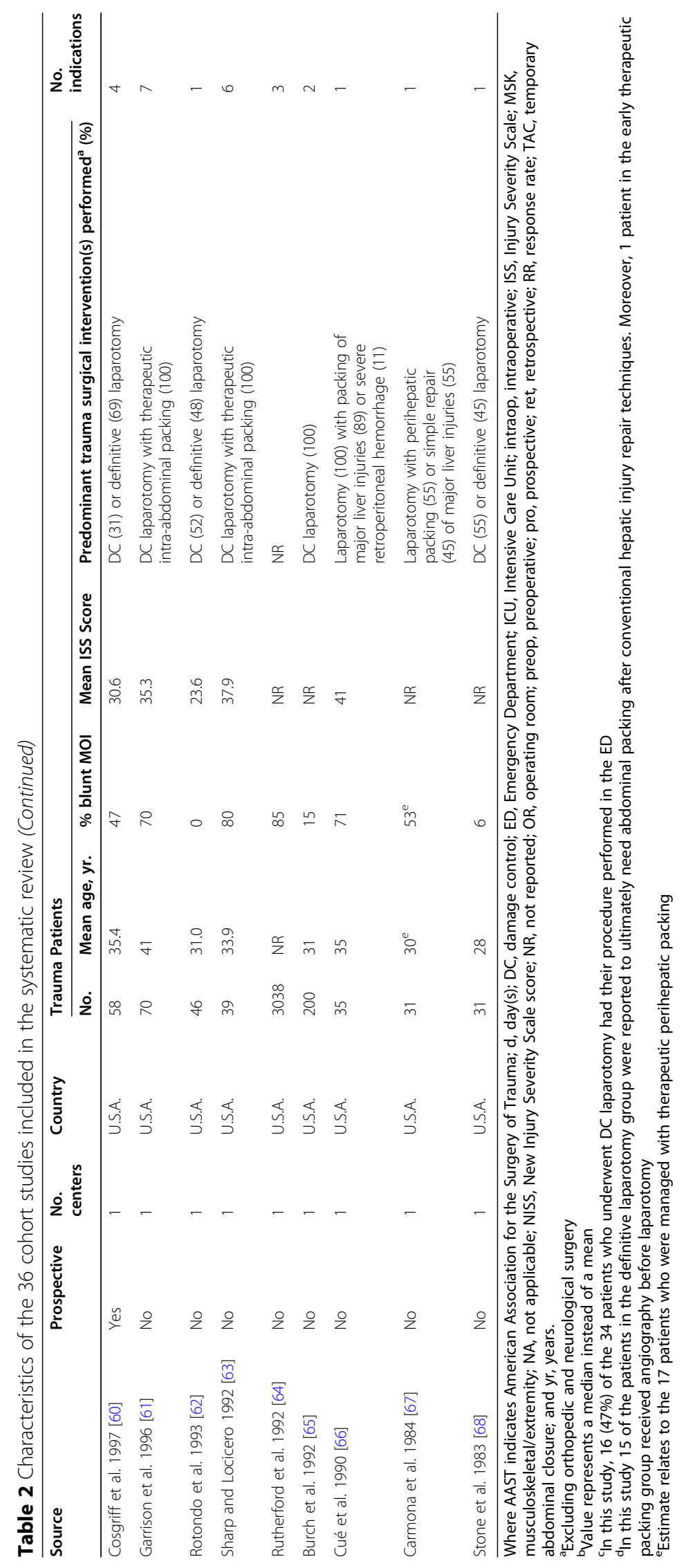


Table 3 Content validity (surgeons would performed damage control in that clinical scenario or the indication predicts use of damage control in practice) of reported indications for use of damage control surgery or damage control interventions in civilian trauma patients

\begin{tabular}{llll}
\hline $\begin{array}{l}\text { Indication (variable included in statistical } \\
\text { analyses) }\end{array}$ & $\begin{array}{l}\text { Confounding } \\
\text { factors adjusted } \\
\text { for }\end{array}$ & Outcome & Content validity \\
\hline
\end{tabular}

Surgeon opinions on the content validity of indications for use of TAC/open abdominal management after laparotomy in cross-sectional studies

Prep for a second look [69]

Abdominal organ distention [69]

Inability to close the fascia [69]

Physically unable to close the fascia [70]

Planned reoperation [70]

Intra-abdominal packing [70]

Magnitude of injury/gestalt [70]

Airway pressure measurements [70]

Bladder pressure measurements [70]

Visual edema of the bowel [70]

Young previously healthy male; grade IV spleen injury identified at laparotomy; massive hemoperitoneum (20\% blood volume loss); no other intra- or extraabdominal injuries; 45 min laparotomy; given $4 \mathrm{~L}$ crystalloid and $4 \mathrm{U}$ PRBCs; intraoperative temperature $36.2^{\circ} \mathrm{C}, \mathrm{pH} 7.34$; INR 1.3; and

[71]

Fascial closure possible without excessive tension

Fascial closure extremely tight

Fascial closure physically not possible but skin closure is

Neither fascial nor skin closure is possible
NA

NA

Percentage of respondents who would leave the abdomen open

Percentage of respondents supporting relevance of indications for leaving the abdomen open after trauma laparotomy

$6 \%$

$22 \%$

$87 \%$

$80 \%$

$59 \%$

$43 \%$

$41 \%$

$39 \%$

$33 \%$

NA

Percentage of respondents who would perform TAC

Same as the above scenario except a splenectomy was performed; intraoperative temperature $34{ }^{\circ} \mathrm{C}, \mathrm{pH} 7.16$, and INR 2.0; and [71]

Fascial closure possible without excessive tension

Fascial closure extremely tight

Fascial closure physically not possible but skin closure is

Neither fascial nor skin closure is possible

Young previously healthy male; presented with severe hemorrhagic shock ( $40 \%$ blood volume loss); bleeding grade III stellate liver rupture with devitalization of $30 \%$ of the right hepatic lobe, grade IV spleen injury which is no longer bleeding, $6 \mathrm{~cm}$ diaphragmatic tear, devascularization of a 6 $\mathrm{cm}$ segment of small bowel, and a one-third thickness circumferential tear of the distal descending colon; after packing of liver and spleen and repair of the diaphragm, major bleeding appears controlled, but there is diffuse oozing from cut surfaces; BP is 80/40 $\mathrm{mmHg}$ with vasopressors and after infusion of $8 \mathrm{~L}$ of crystalloid and $16 \mathrm{U}$ PRBCs; intraoperative temperature $34^{\circ} \mathrm{C}, \mathrm{pH} 7.16$, and INR 2.0; and fascial closure without tension is 
Table 3 Content validity (surgeons would performed damage control in that clinical scenario or the indication predicts use of damage control in practice) of reported indications for use of damage control surgery or damage control interventions in civilian trauma patients (Continued)

\begin{tabular}{llll}
\hline $\begin{array}{l}\text { Indication (variable included in statistical } \\
\text { analyses) }\end{array}$ & $\begin{array}{l}\text { Confounding } \\
\text { factors adjusted } \\
\text { for }\end{array}$ & Outcome & Content validity \\
\hline possible [71] & NA & $\begin{array}{l}\text { Percentage of respondents who } \\
\text { were much less or less willing to } \\
\text { Subjectively tight closure [72] }\end{array}$ & $\begin{array}{l}\text { close the abdomen after trauma } \\
\text { laparotomy }\end{array}$ \\
Massive bowel edema [72] & & $21 \%$ \\
Multiple intra-abdominal injuries [72] & & $71 \%$ \\
Intra-abdominal packing [72] & & $12 \%$ \\
Fecal contamination/peritonitis [72] & & $19 \%$ \\
Massive transfusion [72] & & $21 \%$ \\
Hypothermia [72] & & $22 \%$ \\
Acidosis (pH <7.3) [72] & & $31 \%$ \\
Coagulopathy [72] & & $76 \%$ \\
Planned reoperation [72] & & $94 \%$ \\
Pulmonary deterioration on closure [72] & & $91 \%$ \\
Hemodynamic instability with closure [72] & & &
\end{tabular}

Association between indications and use of DC in practice [as predicted by cohort studies estimating the association (e.g., OR or HR for conducting DC) between certain clinical scenarios and the decision to conduct DC in practice]

Preoperative indications

High ISS [15]

Systolic BP $<90 \mathrm{mmHg}$ on admission and grade III-V liver injury [46]

An artificial neural network including variables for bullet wound location (right or left chest or upper or lower abdominal quadrant) and trajectory pattern [horizontal shift (e.g., one that traversed the abdomen from RUQ to LUQ) or entry wound in back] and lowest ED systolic BP predicted that DC laparotomy would be used in patients with a horizontal shift upper abdominal trajectory pattern and a systolic BP $<105 \mathrm{mmHg}$ or a $R \cup Q$ wound with a bullet retained in the same quadrant and a systolic BP $<90 \mathrm{mmHg}$ [55]

Intraoperative indications

Major abdominal vascular injury [15]

Combined AAST grade III-V liver and IV-V spleen injury [46]

AAST grade $V$ liver injury [46]
Study site, penetrating mechanism, major abdominal vascular injury

None

Bullet wound

location and trajectory pattern, lowest ED systolic $\mathrm{BP}$

Study site, ISS penetrating mechanism

None

Use of DCL

NR

Use of DCL

Pre- or intraoperative indications (or indications for which the setting was unclear or not specified)

Multiple trauma and AAST grade III-V liver in- NR jury [46]

Transfusion > $10 \mathrm{U}$ PRBCs and AAST grade NR
Use of DCL

Use of DCL
OR per ISS $\uparrow, 1.05(95 \% \mathrm{Cl}, 1.02-1.07)$

Not associated with use of DCL

Model Se, 83\%; model Sp, 93\%
$\mathrm{OR}, 2.70(95 \% \mathrm{Cl}, 1.42-5.16)$

All patients with this injury pattern underwent DCL while $42 \%$ of those without it did not $(p=0.02)$

Not associated with $\uparrow$ use of DCL when compared to patients with grade III-IV injury

Not associated with use of DCL

Not associated with use of DCL 
Table 3 Content validity (surgeons would performed damage control in that clinical scenario or the indication predicts use of damage control in practice) of reported indications for use of damage control surgery or damage control interventions in civilian trauma patients (Continued)

\begin{tabular}{|c|c|c|c|}
\hline $\begin{array}{l}\text { Indication (variable included in statistical } \\
\text { analyses) }\end{array}$ & $\begin{array}{l}\text { Confounding } \\
\text { factors adjusted } \\
\text { for }\end{array}$ & Outcome & Content validity \\
\hline \multicolumn{4}{|l|}{ III-V liver injury [46] } \\
\hline Transfusion of a large volume of PRBCs [41] & $\begin{array}{l}\text { FFP and fluids } \\
\text { administered, BD, } \\
\text { lactate }\end{array}$ & Use of DCL & OR per PRBC $\cup \uparrow, 1.05(95 \% \mathrm{Cl}, 0.85-1.29)$ \\
\hline Transfusion of a large volume of FFP [41] & $\begin{array}{l}\text { PRBCs and fluids } \\
\text { administered, BD, } \\
\text { lactate }\end{array}$ & Use of DCL & OR per FFP $\cup \uparrow, 0.95$ (95\% Cl, 0.77-1.18) \\
\hline $\begin{array}{l}\text { Administration of a large volume of fluids } \\
\text { [41] }\end{array}$ & $\begin{array}{l}\text { PRBCs and FFP } \\
\text { administered, BD, } \\
\text { lactate }\end{array}$ & Use of DCL & $\begin{array}{l}\text { OR per } L \text { of fluids } \uparrow, 1.13(95 \% \mathrm{Cl}, 0.92- \\
1.37)\end{array}$ \\
\hline $\begin{array}{l}\text { A PRBC transfusion volume that exceeds the } \\
\text { CAT [39] }\end{array}$ & $\begin{array}{l}\text { Admission systolic } \\
\text { BP, MOI, NISS }\end{array}$ & Use of DCL & $\mathrm{HR}, 2.72(95 \% \mathrm{Cl}, 1.26-5.91)$ \\
\hline $\begin{array}{l}\text { The number of times the PRBC transfusion } \\
\text { volume exceeds the CAT [39] }\end{array}$ & $\begin{array}{l}\text { Admission systolic } \\
\text { BP, MOI, NISS }\end{array}$ & Use of DCL & $\begin{array}{l}\text { HR per CAT multiple, } 1.27 \text { ( } 95 \% \text { Cl, } 1.11- \\
\text { 1.47) (survival was } 89.3 \%, 66.7 \%, 64.3 \% \\
\text { and } 75 \% \text { in CATO, CAT1, CAT2, and CAT3 } \\
\text { pts, respectively )[39] }\end{array}$ \\
\hline Elevated BD (max BD) [41] & $\begin{array}{l}\text { PRBCs, FFP, and } \\
\text { fluids transfused, } \\
\text { lactate }\end{array}$ & Use of DCL & OR per max $\mathrm{BD} \uparrow, 1.25(95 \% \mathrm{Cl}, 0.97-1.61)$ \\
\hline Elevated lactate (max lactate) [41] & $\begin{array}{l}\text { PRBCs, FFP, and } \\
\text { fluids transfused, BD }\end{array}$ & Use of DCL & $\begin{array}{l}\text { OR per max lactate } \uparrow, 0.94 \text { (95\% Cl, } 0.73- \\
1.22)\end{array}$ \\
\hline
\end{tabular}

Where AAST indicates American Association for the Surgery of Trauma; BD, base deficit; BP, blood pressure; CAT, critical administration threshold ( $\geq 3$ units of packed red blood cells administered in $1 \mathrm{~h}$ of the first $24 \mathrm{~h}$ of injury); DC, damage control; DCL, damage control laparotomy; ED, Emergency Department; GSW, gunshot wound; ISS, Injury Severity Scale score; INR, international normalized ratio; LUQ, left upper quadrant; pts, patients; NA, not applicable; PPV, positive predictive value; PRBCs, packed red blood cells; RUQ, right upper quadrant; Se, sensitivity; Sp, specificity; and TAC, temporary abdominal closure

${ }^{a}$ The definition of TAC in this study did not include mesh fascial closures

laparotomy), or signs of abdominal compartment syndrome developed upon attempted fascial closure [6972].

Of the cohort studies that evaluated indication content validity (i.e., whether the indication predicted use of DC in practice), Hirshberg et al. reported that an artificial neural network containing torso bullet wound location/trajectory pattern and systolic blood pressure (BP) in the emergency department (ED) had a high sensitivity (83\%) and specificity (93\%) for identifying patients treated with DC laparotomy [55]. Further, Watson et al. reported that a major abdominal vascular injury was independently associated with the decision to conduct DC laparotomy among patients enrolled in in the Pragmatic, Randomized Optimal Platelet and Plasma Ratios (PROPPR) randomized trial [15]. Another study by Leppäniemi et al. reported that all patients with a AAST grade III-V liver and IV-V spleen injury underwent DC laparotomy while $42 \%$ of those without this injury pattern did not $(p=0.02)$ [46]. Finally, Savage et al. reported that packed red blood cell (PRBC) transfusion volumes exceeding the critical administration threshold ( $\geq 3$ U PRBCs in 1 hour of the first $24 \mathrm{~h}$ of injury) were independently associated with a dosedependent increase in use of DC laparotomy [39].

\section{Construct validity}

The construct validity of indications (or predictive models containing a combination of indications, other clinical findings, and/or baseline demographic variables) for DC surgery was evaluated in 23 studies, which examined associations between indications and survival or coagulopathy (Table 4). Three studies reported that a high ISS score, preoperative hypothermia, an elevated base deficit in the pre- or intraoperative setting, and the identification of a combined pancreas and abdominal vascular injury during operation were independently associated with decreased survival in patients mostly treated with definitive surgery, suggesting that DC should be considered in these high-risk scenarios [44, $57,64]$. Interestingly, however, a preoperative $\mathrm{pH}<7.20$ was also independently associated with decreased survival among injured patients who received DC laparotomy in another study (suggesting that it was also a poor prognostic factor among those treated with DC) [47]. Two other studies evaluated the association between development of a laboratory-confirmed coagulopathy (variably defined), a clinical scenario where DC has long been recommended over definitive surgery, and an ISS score $>25$, systolic $\mathrm{BP}<70 \mathrm{mmHg}$, or lowest 
Table 4 Construct validity (how well one indication or a combination of indications and demographic variables predicted patient outcomes in patients not treated with damage control) of reported indications for use of damage control surgery in civilian trauma patients

\begin{tabular}{|c|c|c|c|c|}
\hline Indication (variable included in statistical analyses) & $\begin{array}{l}\% \text { DC } \\
\text { pts in } \\
\text { the } \\
\text { study }\end{array}$ & $\begin{array}{l}\text { Confounding factors } \\
\text { adjusted for }\end{array}$ & Outcome & Predictive validity \\
\hline \multicolumn{5}{|l|}{ Preoperative indications } \\
\hline \multicolumn{5}{|l|}{ Overall injury burden } \\
\hline \multirow[t]{2}{*}{ High ISS } & 0 & $\mathrm{BD}$, temperature & Survival & $\begin{array}{l}\text { BD, temperature OR per ISS } \uparrow, 1.12(95 \% \mathrm{Cl}, 1.03 \text { to } \\
\text { 1.23) [57] }\end{array}$ \\
\hline & 100 & None & Survival & $\begin{array}{l}\uparrow \text { mean ISS in non-survivors vs. survivors ( } 38 \text { vs. } 29, p \\
<0.05 \text { ) [61] }\end{array}$ \\
\hline \multicolumn{5}{|l|}{ Volume and/or type of resuscitation provided } \\
\hline Transfusion of a large volume of PRBCs & 100 & None & Survival & $\begin{array}{l}\uparrow \text { mean U PRBCs transfused in non-survivors vs. survi- } \\
\text { vors ( } 20 \text { vs. } 14, p<0.01)[61]\end{array}$ \\
\hline \multicolumn{5}{|l|}{ Degree of physiologic insult } \\
\hline Prolonged duration of hypotension & 100 & None & Survival & $\begin{array}{l}\uparrow \text { mean duration of preoperative hypotension in non- } \\
\text { survivors vs. survivors ( } 90 \text { vs. } 50 \text { min., } p<0.05 \text { ) [61] }\end{array}$ \\
\hline Hypothermia (min temperature) & 0 & $\mathrm{BD}, \mathrm{ISS}$ & Survival & $\begin{array}{l}\text { OR per min temperature } \downarrow \text { in }{ }^{\circ} \mathrm{C}, 0.32(95 \% \mathrm{Cl}, 0.15 \text { to } \\
\text { 0.64) [57] }\end{array}$ \\
\hline Temperature $<35^{\circ} \mathrm{C}$ & 100 & Age, $\mathrm{BD}, \mathrm{pH}$ & Survival & $\begin{array}{l}\downarrow \text { temperature not independently associated with } \\
\text { survival [47] }\end{array}$ \\
\hline Elevated BD (max BD) & 0 & ISS, temperature & Survival & OR per $\max \mathrm{BD} \uparrow, 0.66(95 \% \mathrm{Cl}, 0.56$ to 0.78$)$ [57] \\
\hline $\mathrm{BD}>10.5 \mathrm{mEq} / \mathrm{L}$ & 100 & Age, pH, temperature & Survival & $\uparrow$ BD not independently associated with survival [47] \\
\hline Decreased pH & 100 & None & Survival & $\begin{array}{l}\downarrow \text { mean } \mathrm{pH} \text { in non-survivors vs. survivors (7.1 vs. 7.3, } p \\
<0.05)[61]\end{array}$ \\
\hline $\mathrm{pH}<7.20$ & 100 & Age, BD, temperature & Survival & $\begin{array}{l}\uparrow p H \text { independently associated with } \downarrow \text { survival ( } p= \\
0.001 \text { ) [47] }\end{array}$ \\
\hline Decreased platelet count & 100 & None & Survival & $\begin{array}{l}\downarrow \text { mean platelet count in non-survivors vs. survivors } \\
\left(179,000 \text { vs. } 229,000 \mathrm{~mm}^{3}\right)[61]\end{array}$ \\
\hline Laboratory-confirmed coagulopathy & 100 & None & Survival & $\begin{array}{l}\uparrow \text { mean PT ( } 22 \text { vs. } 14 \text { s) and PTT ( } 69 \text { vs. } 42 \text { s) in non- } \\
\text { survivors vs. survivors ( } p<0.05 \text { for both) [61] }\end{array}$ \\
\hline $\mathrm{PT} \geq 16 \mathrm{~s}$ & 100 & None & Survival & OR, $0.11(p<0.05)[63]$ \\
\hline $\mathrm{P} T \mathrm{~T} \geq 50 \mathrm{~s}$ & 100 & None & Survival & $\begin{array}{l}\text { OR, } 0 \text { (survival, } 0 \% \text { vs. } 71 \% \text { with PTT }<50 \text { sec; } p<0.05 \text { ) } \\
\text { [63] }\end{array}$ \\
\hline $\begin{array}{l}\text { A model included highest ED BD, lowest ED } \\
\text { temperature, and ISS }\end{array}$ & 0 & $\begin{array}{l}\text { BD, lowest ED temperature, } \\
\text { ISS }\end{array}$ & Survival & Model Se, 83\%; model Sp, 93\% [57] \\
\hline $\begin{array}{l}\text { A model predicting that survival was possible only } \\
\text { when the equation } 0.012 \text { (age) }-0.707 \text { (lowest } \\
\text { preoperative } \mathrm{pH})-0.032 \text { (lowest preoperative } \\
\left.\text { temperature in }{ }^{\circ} \mathrm{C}\right)+6.002=<0.5\end{array}$ & 100 & None & Survival & Model Se, 25\%; model PPV, 100\% [49] \\
\hline \multicolumn{5}{|l|}{ Intraoperative indications } \\
\hline \multicolumn{5}{|l|}{ Injury pattern identified during operation } \\
\hline \multirow{2}{*}{$\begin{array}{l}\text { Combined abdominal vascular and pancreas gunshot } \\
\text { injuries }\end{array}$} & 20 & 12 variables $^{a}$ & Survival & OR, $0.12(95 \% \mathrm{Cl}, 0.041-0.36)[44]$ \\
\hline & 20 & 11 variables $^{a}$ & Complications & OR, $3.59(95 \% \mathrm{Cl}, 1.10-11.68)[44]$ \\
\hline $\begin{array}{l}\text { Iliac vessel injury and prolonged duration of } \\
\text { hypotension }\end{array}$ & 22 & None & Survival & $\begin{array}{l}\uparrow \text { mean duration of hypotension in non-survivors vs. } \\
\text { survivors who underwent definitive }(95 \text { vs. } 65 \text { min, } p \\
\text { value NR) and DC ( } 40 \text { vs. } 85 \text { min, } p<0.05 \text { ) laparotomy } \\
\text { [58] }\end{array}$ \\
\hline Iliac vessel injury and initial temperature $<34{ }^{\circ} \mathrm{C}$ & 17 & None & Survival & OR, $0.27(95 \% \mathrm{Cl}, 0.072-1.0)[59]$ \\
\hline Iliac vessel injury and final temperature $<35^{\circ} \mathrm{C}$ & 17 & None & Survival & OR, 0.025 (95\% Cl, 0.0028-0.23) [59] \\
\hline \|liac vessel injury and initial $B D>15 \mathrm{mEq} / \mathrm{L}$ & 17 & None & Survival & OR, 0.037 (95\% Cl, 0.0072-0.19) [59] \\
\hline Iliac vessel injury and final BD $>6 \mathrm{mEq} / \mathrm{L}$ & 17 & None & Survival & OR, $0.091(95 \% \mathrm{Cl}, 0.019-0.45)[59]$ \\
\hline Iliac vessel injury and initial $\mathrm{pH}<7.1$ & 17 & None & Survival & OR, $0.032(95 \% \mathrm{Cl}, 0.0055-0.19)[59]$ \\
\hline \|liac vessel injury and final $\mathrm{pH}<7.3$ & 17 & None & Survival & OR, $0.069(95 \% \mathrm{Cl}, 0.014-0.36)[59]$ \\
\hline Penetrating iliac vessel injury and final $\mathrm{pH}<7.2$ & 22 & None & Survival & $\begin{array}{l}\downarrow \text { mean final } \mathrm{pH} \text { in non-survivors vs. survivors who } \\
\text { underwent definitive }(7.11 \text { vs. } 7.29, p \text { value NR) and } \\
\text { DC (7.20 vs. } 7.32, p \text { value }<0.05)[58]\end{array}$ \\
\hline
\end{tabular}


Table 4 Construct validity (how well one indication or a combination of indications and demographic variables predicted patient outcomes in patients not treated with damage control) of reported indications for use of damage control surgery in civilian trauma patients (Continued)

\begin{tabular}{|c|c|c|c|c|}
\hline Indication (variable included in statistical analyses) & $\begin{array}{l}\% \text { DC } \\
\text { pts in } \\
\text { the } \\
\text { study }\end{array}$ & $\begin{array}{l}\text { Confounding factors } \\
\text { adjusted for }\end{array}$ & Outcome & Predictive validity \\
\hline Penetrating iliac vessel injury and final PT $>20 \mathrm{~s}$ & 22 & None & Survival & $\begin{array}{l}\uparrow \text { final PT in non-survivors vs. survivors who under- } \\
\text { went definitive ( } 25.2 \text { vs. } 17.8 \mathrm{sec}, p \text { value NR) and DC } \\
(20.2 \text { vs. } 15.9 \mathrm{~s}, p<0.05) \text { laparotomy [58] }\end{array}$ \\
\hline Penetrating iliac vessel injury and final PTT $>70 \mathrm{~s}$ & 22 & None & Survival & $\begin{array}{l}\uparrow \text { final } P T T \text { in non-survivors vs. survivors who under- } \\
\text { went definitive ( } 86.1 \text { vs. } 59.2 s, p \text { value NR) and DC } \\
(66.2 \text { vs. } 47.8 s, p<0.05) \text { laparotomy [58] }\end{array}$ \\
\hline $\begin{array}{l}\text { Iliac vessel injury and shock, hypothermia, acidosis, or } \\
\text { coagulopathy (timing of measurement not specified) }\end{array}$ & 18 & $\leq 14$ variables $^{\text {b }}$ & Survival & $\begin{array}{l}\text { Shock, hypothermia, acidosis, and coagulopathy not } \\
\text { independently associated with survival [54] }\end{array}$ \\
\hline \multicolumn{5}{|l|}{ Volume and/or type of resuscitation provided } \\
\hline Transfusion $>4$ L PRBCs & 100 & 23 variables $^{b}$ & Survival & Independently associated with $\downarrow$ survival [56] \\
\hline Transfusion > 5 L PRBCs and whole blood & 100 & None & Survival & $\begin{array}{l}\uparrow \text { mean volume of PRBCs and whole blood in non- } \\
\text { survivors vs. survivors }(8.2 \text { vs. } 5.6 \mathrm{~L}, p<0.001)[56]\end{array}$ \\
\hline $\begin{array}{l}\text { Administration > } 12 \mathrm{~L} \text { PRBCs and/or whole blood, } \\
\text { other blood products, and crystalloids }\end{array}$ & 100 & None & Survival & $\begin{array}{l}\uparrow \text { mean volume of these fluids in non-survivors vs. sur- } \\
\text { vivors (15.0 vs. } 12.4 L, p<0.001 \text { ) [56] }\end{array}$ \\
\hline \multicolumn{5}{|l|}{ Degree of physiologic insult } \\
\hline Temperature $\leq 34{ }^{\circ} \mathrm{C}$ & 100 & None & Survival & $\begin{array}{l}\downarrow \text { mean min temperature in non-survivors vs. survivors } \\
(33.9 \text { vs. } 35.0, p<0.001)[56]\end{array}$ \\
\hline Serum $\left[\mathrm{HCO}_{3}\right] \leq 15 \mathrm{mEq} / \mathrm{L}$ & 100 & None & Survival & $\begin{array}{l}\text { Serum }\left[\mathrm{HCO}_{3}{ }^{-}\right] \leq 15 \mathrm{mEq} / \mathrm{L} \text { associated with } \downarrow \text { survival } \\
{[56]}\end{array}$ \\
\hline $\mathrm{pH}<7.2$ & 100 & None & Survival & $\begin{array}{l}\downarrow \text { mean initial }(7.1 \text { vs. } 7.4) \text {, max }(7.2 \text { vs. } 7.4) \text {, and min } \\
(7.0 \text { vs. } 7.2) \mathrm{pH} \text { in non-survivors vs. survivors }(p<0.001 \\
\text { for all) [56] }\end{array}$ \\
\hline Elevated $\mathrm{ACT}$ & 23 & Unclear for logistic regression & $\begin{array}{l}\text { Clinical } \\
\text { coagulo- } \\
\text { pathy }^{c}\end{array}$ & $\begin{array}{l}\text { The mean of } 2 \text { ACT measurements (taken within the } \\
\text { first } 10 \text { min of beginning surgery and repeated } \sim 15 \\
\text { min later) was } 180 \mathrm{~s} \text { in patients with coagulopathy } \\
\text { versus } 118 \mathrm{~s} \text { in those without }(p<0.001) \text { [53] The } 1^{\text {st }} \text {, } \\
2^{\text {nd }} \text {, and mean ACT values were independently } \\
\text { associated with coagulopathy using logistic regression } \\
(p \text { value NR) [53] }\end{array}$ \\
\hline $\begin{array}{l}\text { Systolic } \mathrm{BP}<90 \mathrm{mmHg}, \mathrm{BD}>7.5 \mathrm{mEq} / \mathrm{L} \text {, and/or } \\
\text { temperature }<35.5^{\circ} \mathrm{C} \text { at the start of surgery }\end{array}$ & 100 & None & Survival & $\begin{array}{l}\text { OR for survival was } 0.13 \text { ( } 95 \% \mathrm{Cl}, 0.021-0.77 \text { ) among } \\
\text { patients who presented with all } 3 \text { vs. }<3 \text { variables. } \\
\text { There was also a stepwise } \downarrow \text { in survival as the no. of } \\
\text { variables present } \uparrow[48]\end{array}$ \\
\hline $\begin{array}{l}\text { A model predicted that survival was only possible } \\
\text { when patients lie below and to the right of a diagonal } \\
\text { discriminant line given by the equation PRBC } \\
\text { transfusion rate }(\mathrm{U} / \mathrm{h})=35.7 \text { (arterial } \mathrm{pH})-242 \text { (for an } \\
\text { arterial } \mathrm{pH}=7.2 \text {, transfusion rate }=15 \mathrm{U} / \mathrm{h} \text { ) }\end{array}$ & 100 & PRBC transfusion rate, $\mathrm{pH}$ & 48 h survival & Model Se, 77\% [65] \\
\hline \multicolumn{5}{|c|}{ Pre- or intraoperative indications (or indications for which the setting was unclear or not specified) } \\
\hline \multicolumn{5}{|l|}{ Volume and/or type of resuscitation provided } \\
\hline Transfusion $>15 \cup$ PRBCs & 100 & None & Coagulopathy $^{d}$ & $\mathrm{OR}, 6.0(95 \% \mathrm{Cl}, 0.67-75.61)[66]$ \\
\hline $\begin{array}{l}\text { Transfusion }>10 \cup \text { PRBCs in the first } 24 \mathrm{~h} \text { and an ISS } \\
>25\end{array}$ & 31 & $\begin{array}{l}\text { PRBCs transfused in } 24 \mathrm{~h} \text {, } \\
\text { lowest systolic } \mathrm{BP}<70 \\
\mathrm{mmHg}, \mathrm{pH}<7.1 \text {, and } \\
\text { temperature }<34^{\circ} \mathrm{C}\end{array}$ & $\begin{array}{l}\text { PT \& PTT > } \\
2^{\mathrm{a}} \text { control }\end{array}$ & $\mathrm{OR}, 7.7(95 \% \mathrm{Cl}, 1.5-38.8)[60]^{\mathrm{e}}$ \\
\hline $\begin{array}{l}\text { Transfusion }>10 \cup \text { PRBCs in the first } 6 \mathrm{~h} \text { and an ISS } \\
>25\end{array}$ & NR & 9 variables $^{f}$ & $\mathrm{INR}>1.5$ at 6 & $\mathrm{OR}, 4.14(95 \% \mathrm{Cl}, 0.57-3.18)[50]$ \\
\hline $\begin{array}{l}\text { Transfusion }>10 \cup \text { PRBCs in the first } 24 \mathrm{~h} \text { and the } \\
\text { lowest systolic } \mathrm{BP}<70 \mathrm{mmHg}\end{array}$ & 31 & $\begin{array}{l}\text { ISS }>25, \text { PRBCS transfused in } \\
24 \mathrm{~h}, \mathrm{pH}<7.1 \text {, and } \\
\text { temperature }<34^{\circ} \mathrm{C}\end{array}$ & $\begin{array}{l}\mathrm{PT} \& \mathrm{PTT}> \\
2^{\mathrm{a}} \text { control }\end{array}$ & OR, $5.8(95 \% C l, 1.2-28.2)[60]^{e}$ \\
\hline $\begin{array}{l}\text { Transfusion }>10 \cup \text { PRBCs in the first } 6 \mathrm{~h} \text { and ED } \\
\text { systolic } \mathrm{BP}<70 \mathrm{mmHg}\end{array}$ & NR & 9 variables $^{f}$ & $\mathrm{INR}>1.5$ at 6 & OR, $0.48(95 \% \mathrm{Cl}, 0.10-2.23)[50]$ \\
\hline $\begin{array}{l}\text { Transfusion }>10 \cup \text { PRBCs in the first } 24 \mathrm{~h} \text { and lowest } \\
\text { temperature }<34{ }^{\circ} \mathrm{C}\end{array}$ & 31 & $\begin{array}{l}\text { ISS }>25, \text { PRBCs transfused in } \\
24 \mathrm{~h} \text {, lowest systolic } \mathrm{BP}<70 \\
\mathrm{mmHg} \text {, and } \mathrm{pH}<7.1\end{array}$ & $\begin{array}{l}\mathrm{PT} \& \mathrm{PTT}> \\
2^{\mathrm{a}} \text { control }\end{array}$ & $\mathrm{OR}, 8.7(95 \% \mathrm{Cl}, 1.8-41.8)[60]^{\mathrm{e}}$ \\
\hline $\begin{array}{l}\text { Transfusion }>10 \cup \text { PRBCs in the first } 6 \mathrm{~h} \text { and } \mathrm{ED} \\
\text { temperature }<34^{\circ} \mathrm{C}\end{array}$ & NR & 9 variables $^{f}$ & $\begin{array}{l}\text { INR }>1.5 \text { at } 6 \\
h\end{array}$ & OR, $6.10(95 \% \mathrm{Cl}, 1.54-24.19)$ [50] \\
\hline
\end{tabular}


Table 4 Construct validity (how well one indication or a combination of indications and demographic variables predicted patient outcomes in patients not treated with damage control) of reported indications for use of damage control surgery in civilian trauma patients (Continued)

\begin{tabular}{|c|c|c|c|c|}
\hline Indication (variable included in statistical analyses) & $\begin{array}{l}\% \text { DC } \\
\text { pts in } \\
\text { the } \\
\text { study }\end{array}$ & $\begin{array}{l}\text { Confounding factors } \\
\text { adjusted for }\end{array}$ & Outcome & Predictive validity \\
\hline $\begin{array}{l}\text { Transfusion }>10 \cup \text { PRBCs in the first } 24 \mathrm{~h} \text { and lowest } \\
\mathrm{pH}<7.1\end{array}$ & 31 & $\begin{array}{l}\text { ISS }>25, \text { PRBCs transfused in } \\
24 \mathrm{~h} \text {, lowest systolic } \mathrm{BP}<70 \\
\mathrm{mmHg} \text {, and temperature }< \\
34^{\circ} \mathrm{C}\end{array}$ & $\begin{array}{l}\text { PT \& PTT > } \\
2^{\mathrm{a}} \text { control }\end{array}$ & $\mathrm{OR}, 12.3(95 \% \mathrm{Cl}, 2.4-64.0)[60]^{\mathrm{e}}$ \\
\hline $\begin{array}{l}\text { Transfusion }>10 \cup \text { PRBCs in the first } 6 \mathrm{~h} \text { and } \mathrm{ED} \mathrm{pH}< \\
\text { 7.1 }\end{array}$ & NR & 9 variables $^{f}$ & $\mathrm{INR}>1.5$ at 6 & OR, $1.69(95 \% \mathrm{Cl}, 0.56-5.08)[50]$ \\
\hline \multicolumn{5}{|l|}{ Degree of physiologic insult } \\
\hline Min temperature $\leq 33^{\circ} \mathrm{C}$ & 100 & None & Survival & OR, 0.20 (p-value reported as NS) [63] \\
\hline $\begin{array}{l}\text { Elevated max } B D \text { in the first } 24 \mathrm{~h} \text { in blunt trauma } \\
\text { patients without } \mathrm{TBl}\end{array}$ & NR & Age $\geq 55 \mathrm{yr}$ & Mortality & OR per max BD $\uparrow, 1.39(95 \% \mathrm{Cl}, 1.35$ to 1.41$)$ [64] \\
\hline $\begin{array}{l}\text { Elevated max BD in the first } 24 \mathrm{~h} \text { in penetrating } \\
\text { trauma patients without TBI }\end{array}$ & NR & Age $\geq 55 \mathrm{yr}$ & Mortality & OR per max BD $\uparrow, 1.58(95 \% \mathrm{Cl}, 1.44$ to 1.75$)$ [64] \\
\hline $\begin{array}{l}\text { Elevated max BD in the first } 24 \mathrm{~h} \text { in blunt trauma } \\
\text { patients with } \mathrm{TBI}\end{array}$ & NR & Age $\geq 55 \mathrm{yr}$ & Mortality & OR per max $\mathrm{BD} \uparrow, 1.25(95 \% \mathrm{Cl}, 1.14$ to 1.38$)$ [64] \\
\hline Min $\mathrm{pH} \leq 7.18$ & 100 & None & Survival & OR, $0.17(p<0.05)[63]$ \\
\hline \multicolumn{5}{|l|}{ Miscellaneous } \\
\hline $\begin{array}{l}\text { Transfusion } \geq 10 \cup \mathrm{PRBCs} \text {, lowest ED or intraoperative } \\
\text { temperature } \leq 33^{\circ} \mathrm{C}, \mathrm{PH} \leq 7.18, \mathrm{ED} \mathrm{PT} \geq 16 \mathrm{~s} \text {, or ED } \\
\mathrm{PTT} \geq 50 \mathrm{~s}\end{array}$ & 100 & None & Survival & $\begin{array}{l}\downarrow \text { survival when } 4-5(0 \% \text { vs. } 82 \% ; p<0.04) \text { or } 2-3 \\
(17 \% \text { vs. } 82 \% ; p<0.003) \text { vs. } 0-1 \text { of these indications } \\
\text { were present [63] }\end{array}$ \\
\hline $\begin{array}{l}\text { A model including } \mathrm{BD} \text {, penetrating } \mathrm{MOI}, \mathrm{TBI} \text {, age } \geq 55 \\
\mathrm{yr} \text {, and an interaction between } \mathrm{BD} \text { and penetrating }\end{array}$ & NR & $\begin{array}{l}\mathrm{BD} \text {, penetrating } \mathrm{MOI}, \mathrm{TBl} \text {, age } \\
\geq 55 \mathrm{yr}\end{array}$ & $75 \%$ survival & Model Se, 71\%; model Sp, 89\% [64] \\
\hline
\end{tabular}
for which the probability of survival was $75 \%$ was 15 $\mathrm{mmol} / \mathrm{L}$ for young patients without TBI versus 8 $\mathrm{mmol} / \mathrm{L}$ for patients aged $<55$ yr with a TBI and older patients aged $\geq 55 \mathrm{yr}$

Where ACT, activated coagulation time; BD, base deficit; BP, blood pressure; Cl, confidence interval; DC, damage control; ED, Emergency Department; FFP, fresh frozen plasma; h, hours; HD, hemodynamic; INR, international normalized ratio; ISS, Injury Severity Scale score; max, maximum; min, minimum; MOI, mechanism of injury; NISS, New Injury Severity Scale score; NR, not reported; NS, not significant; OR, operating room; PPV, positive predictive value; PRBCs, packed red blood cells; PT, prothrombin time; PTT, partial thromboplastin time; pts, patients; U, unit(s); Se, sensitivity; Sp, specificity; ULN, upper limit of normal; and yr, years ${ }^{a}$ Variables reported to be entered into the logistic regression model for mortality included age; Revised Trauma Score; systolic BP < 90 mmHg on admission; need for a major transfusion and volume transfused; need for DC surgery; AAST grade III-V pancreas injury and proximal pancreas injury; associated colonic, duodenal, and vascular injuries; postoperative complications; ICU admission; and length of ICU stay. Variables reported to be entered into the logistic regression model for complications included age; Revised Trauma Score; systolic BP $<90 \mathrm{mmHg}$ on admission; need for transfusion and volume of blood transfused; need for DC surgery; grade of pancreas injury; repeat laparotomy; second pancreatic surgery; associated duodenal or vascular injury; intensive care unit (ICU) admission; and length of ICU stay

${ }^{b}$ Variables reported to be entered into the regression model included those associated with mortality $(p<0.20)$ that did not have $>10 \%$ missing data. These may have included, at a minimum, systolic BP and respiratory rate in the ED; Glasgow Coma Scale score, ISS, and Revised Trauma Scale score; preoperative hematocrit; crystalloids and blood given in the ED; estimated intraoperative blood loss; crystalloids and blood given in the OR; total fluids; and length of stay in the surgical intensive care unit and hospital

${ }^{b}$ Variables reported to be entered into the logistic regression model included those associated with survival in bivariate analysis $(p<0.20)$. These appeared to at least include ISS > 20; RTS > 0; GCS $\leq 3$ or < 9; MOl; absence of spontaneous ventilation, a palpable carotid pulse, or extremity movement; non-sinus rhythm on the electrocardiogram; systolic BP and respiratory rate as a 3-level or 2-level categorical variable; a pulmonary artery and vein, thorax, thoracic or abdominal vascular, or liver injury; thoracotomy or laparotomy in the OR; coagulopathy; dysrhythmia; and type of dysrhythmia 'Defined by the authors as the perceived need to initiate DC maneuvers by a surgical attending, which was reported to be subjective, but usually occurred in the setting of major blood loss, hypothermia, acidosis, and the presence of multiple injuries [53]

${ }^{\mathrm{d}}$ Defined by the authors as diffuse bleeding from all wounds without discrete bleeding vessels, absence of observable clots, prolonged PT and PTT along with decreased platelet count, or decreased platelet count alone [66]

In this study, the probability of developing coagulopathy (defined as a PT and PTT $>2$ times that of normal laboratory control) in patients who had received a transfusion of $>10$ Us PRBCs in the first $24 \mathrm{~h}$ was $10 \%$ for those with an ISS $>25 ; 39 \%$ for those with an ISS $>25$ and lowest systolic BP $<70$ mmHg; $58 \%$ for those with an ISS $>25$ and lowest $\mathrm{pH}<7.1 ; 49 \%$ for those with an ISS $>25$ and lowest temperature $<34{ }^{\circ} \mathrm{C} ; 85 \%$ for those with an ISS $>25$ and lowest systolic BP $<70 \mathrm{mmHg}$ and temperature $<34{ }^{\circ} \mathrm{C}$; and $98 \%$ for those with an ISS $>25$ and lowest systolic BP $<70 \mathrm{mmHg}, \mathrm{pH}<7.1$, and temperature $<34{ }^{\circ} \mathrm{C}$. fVariables entered into the logistic regression model included FFP:PRBC ratio at $6 \mathrm{~h}$; age $>55$ years; ISS $>25 ;$ PRBC, FFP, and platelet U transfused at 6 h; crystalloids in $24 \mathrm{~h}$; and ED systolic $\mathrm{BP}<70 \mathrm{mmHg}$, temperature $<34{ }^{\circ} \mathrm{C}$, and $\mathrm{pH}<7.1$ 
temperature $<34{ }^{\circ} \mathrm{C}$ or $\mathrm{pH}<7.1$ in trauma patients transfused $>10$ units of PRBCs in the first 6 or $24 \mathrm{~h}$ [50, 60]. Among these studies, the pooled adjusted OR for development of a laboratory-confirmed coagulopathy among patients with an ISS score $>25$ was 6.11 (95\% CI, $1.68-22.16 ; I^{2}=0 \%$; heterogeneity $p=0.65$ ), systolic BP $<70 \mathrm{mmHg}$ was 1.66 (95\% CI, 0.15-19.10; $I^{2}=79.5 \%$; heterogeneity $p=0.03$ ), lowest temperature $<34{ }^{\circ} \mathrm{C}$ was 7.12 (95\% CI, 2.53-20.05; $I^{2}=0 \%$; heterogeneity $p=$ 0.74 ), and lowest $\mathrm{pH}<7.1$ was 4.14 (95\% CI, 0.60-28.67; $I^{2}=74.2 \%$; heterogeneity $\left.p=0.05\right)$.

\section{Criterion validity}

Two studies evaluated outcomes associated with implementation or utilization of indications for DC surgery while 14 compared outcomes of patients treated with DC versus definitive surgery in different clinical situations (Table 5). Rice et al. reported that, when compared to only minor deviations, moderate or major deviations from a protocol that suggested use of DC surgery in injured patients with a temperature $<35{ }^{\circ} \mathrm{C}$, lactate $>4$ $\mathrm{mmol} / \mathrm{L}$ (or more than twice the upper limit of normal), or corrected $\mathrm{pH}<7.3$ was independently associated with reduced survival [43]. Asensio et al. reported that implementing a guideline that suggested use of DC surgery for trauma patients with one of 12 different clinical findings/events was associated with a decreased unadjusted odds of infections, an increased unadjusted odds of abdominal wall closure, and reduced unadjusted lengths of ICU and hospital stay [52].

Of the remaining 14 studies, Chinnery et al., Rotondo et al., and Stone et al. observed a large improvement in unadjusted survival when DC or staged laparotomy was used instead of definitive surgery to manage unstable patients with combined abdominal vascular and pancreas gunshot injuries, who received $>10 \mathrm{U}$ PRBCs and had $\geq$ 1 major abdominal vascular and $\geq 2$ abdominal visceral injuries, or that developed a coagulopathy during operation, respectively [44, 62, 68]. In contrast, Harvin et al. reported that after matching injured patients on propensity scores created using 17 different variables, use of DC instead of definitive laparotomy (for intra-abdominal packing, a second-look laparotomy, hemodynamic instability, to expedite postoperative care or intervention, or for other reasons) was associated with a significantly increased incidence of gastrointestinal (GI) ileus, GI bleeding, abdominal fascial dehiscence, superficial surgical site infection, and death [38]. Moreover, Martin et al. reported that use of DC laparotomy in trauma patients with an arrival systolic BP $>90 \mathrm{mmHg}$, no severe TBI, and no combined abdominal injuries was associated with an increased adjusted odds of major postoperative complications and an increased adjusted length of hospital stay when compared to patients with a severe abdominal injury who underwent therapeutic definitive laparotomy [14].

\section{Narrative synthesis of validity of indications for use of DC surgery}

The narrative synthesis of the aggregate evidence for use of indications for DC surgery is presented in Table 6. Of the 59 unique indications identified using directed qualitative content analysis, two had moderate or strong evidence of content validity [upper quadrant abdominal gunshot wound with a horizontal shift trajectory (e.g., from the right to the left upper quadrant) and a systolic $\mathrm{BP}<105 \mathrm{mmHg}$ or right upper quadrant wound with a bullet retained in the same quadrant and a systolic $\mathrm{BP}<$ $90 \mathrm{mmHg}$ ). Further, nine had moderate or strong evidence of construct validity (high ISS score, preoperative hypothermia, unstable patients with combined abdominal vascular and pancreas gunshot injuries, and transfusion $>10 \mathrm{U}$ PRBCs and ISS score $>25$ or lowest temperature $<34{ }^{\circ} \mathrm{C}$ in the pre- or intraoperative setting) and six had moderate or strong evidence of criterion validity (pre- or intraoperative hypothermia, increased lactate, or decreased $\mathrm{pH}$ ).

\section{Discussion}

This systematic review is the first to comprehensively compile and critically analyze the evidence for use of DC surgery and DC interventions in civilian trauma patients. We identified 39 studies that evaluated the content, construct, and/or criterion validity of 116 indications for DC surgery. Most were single-center cohort studies that recruited relatively small samples of critically injured patients. Of the 59 unique indications identified using content analysis, 10 had evidence of content validity (i.e., surgeons self-reported that they would perform DC in that clinical scenario or the indication predicted use of DC in practice), nine had evidence of construct validity (i.e., were associated with poor outcomes in patients largely treated with definitive surgery, suggesting that DC be considered in these high-risk scenarios), and six had evidence of criterion validity (may be associated with improved outcomes when utilized or when DC was performed instead of definitive surgery).

Most included studies attempted to validate indications for use of DC surgery by assessing if they were associated with poor outcomes (i.e., coagulopathy or reduced survival); however, few studies subsequently sought to determine if DC improves survival in these situations and nearly one quarter of these studies included patients who only underwent DC (and therefore outcomes associated with these variables are better interpreted as predictors of poor outcome after DC surgery than measures of indication construct validity). Further, some physiology-based indications were associated with 
Table 5 Criterion validity (extent to which the utilization or conduct of damage control instead of definitive surgery for one or more indications was associated with patient outcomes) of reported indications for use of damage control surgery or damage control interventions

\section{Source Treatment or exposure group $(n) \quad$ Comparison group $(n) \quad$ Confounding Outcome(s) \\ adjusted for}

Harvin DC laparotomy $(n=144)$ for intra- Definitive laparotomy $(n=78)$

et al. 2016 abdominal packing (68\%), a second-

look laparotomy (6\%), hemodynamic instability (15\%), to expedite postoperative care or intervention (8\%), abdominal compartment syndrome prophylaxis (1\%), contamination (1\%), or for other/unclear reasons (1\%)
Ordoñez et al. 2014 [40]

Thompson et al. 2013 [42]

Rice et al 2012 [43]

Martin et al. 2012 [14]

Chinnery et al. 2012 [44]

Mayberry et al. 2011 [45]

Liu et al. 2011 [24]
DC laparotomy with primary duodenal repair $(n=14)$ for complex penetrating AAST grade II-IV duodenal injuries

DC surgery with or without the first stage of a Whipple procedure for patients with severe pancreaticoduodenal trauma $(n=12)$
Those who had no or minor deviations from the DC surgery protocol $(n=358)^{b}$ suggested use of DC surgery when any of the following were present: temperature $<35^{\circ} \mathrm{C}$, lactate $>4 \mathrm{mmol} /$ $\mathrm{L}$ (or more than twice the ULN), or corrected $\mathrm{pH}<7.3(n=92)^{\mathrm{a}}$

DC laparotomy for patients with an arrival systolic BP > $90 \mathrm{mmHg}$, no severe TBI (head AIS score <3), and no $>2$ combined abdominal injuries $(n=62)$

DC surgery for unstable patients with pancreatic and major associated organ and visceral vascular injuries $(n=43)$

DC laparotomy for patients with fullthickness duodenal lacerations $(n=25)$

DC laparotomy for patients with a preoperative temperature $<35^{\circ} \mathrm{C}$, PT $>16 \mathrm{~s}, \mathrm{PTT}>50 \mathrm{~s}$, or $\mathrm{pH}<7.3$ or who received $>10 \cup \operatorname{PRBCs}(n=46)$ $>2$ with this indication $(n=32)$ this indication $(n=16)$ with these indications $(n=58)$
Definitive laparotomy with primary duodenal repair for complex penetrating AAST grade II-IV duodenal injuries $(n=7)$

A complete Whipple procedure (including reconstruction) at the index operation for patients with severe pancreaticoduodenal trauma $(n=3)$
Propensity The adjusted incidence of ileus was scores created $13 \%(95 \% \mathrm{Cl}, 6-26 \%)$ higher in the DC using 17 different variables $^{a}$ versus definitive laparotomy group The adjusted incidence of suture line failure was 7\% (95\% Cl, 0-14\%) higher in the DC versus definitive laparotomy group

The adjusted incidence of $\mathrm{Gl}$ bleed was 4\% (95\% Cl, 0-7\%) higher in the DC versus definitive laparotomy group The adjusted incidence of abdominal fascial dehiscence was $11 \%(95 \%$ Cl, $2-$ 19\%) higher in the DC versus definitive laparotomy group

The adjusted incidence of superficial SSI was 19\% (95\% Cl, 10-28\%) higher in the DC versus definitive laparotomy group

The adjusted incidence of death was $18 \%(95 \% \mathrm{Cl}, 11-26 \%)$ higher in the DC versus definitive laparotomy group
None

None for all comparisons

3 variables $^{c}$ Survival was $92.9 \%$ in the DC versus $100 \%$ in the definitive laparotomy group $(p>0.99)$

Survival was $83.3 \%$ in the DC versus $100 \%$ in the complete Whipple group $(p>0.99)$ Sepsis occurred in $16.7 \%$ of the DC versus $100 \%$ of the complete Whipple group $(p=0.01)$ Enterocutaneous/enteroatmospheric fistulae occurred in $8.3 \%$ of the DC versus $66.7 \%$ of the complete Whipple group $(p=0.04)$

Survival at $90 \mathrm{~d}$ : adjusted OR, 0.50 (95\% $\mathrm{Cl}, 0.27-0.92)$

Therapeutic definitive laparotomy in patients with an abdomen AIS score

Before use of DC surgery for patients

Definitive surgery for patients with

Definitive laparotomy for patients
10 variables $^{d}$

Major postoperative complication: adjusted OR, 2.96 (95\% Cl, 1.25-6.99) The adjusted length of hospital stay was $9.69 \mathrm{~d}$ longer in patients who laparotomy $(p<0.001)$

None for both comparisons

urvival: OR, 0.082 (95\% Cl, 0.014-0.34) Postoperative complications (systemic, pancreatic, and intra-abdominal): OR, 8.02 (95\% Cl, 1.44-80.24)

None

Duodenal-related complications: OR, 0.38 (95\% Cl, 0.029-3.83)

None for both Survival: OR, 3.51 (95\% Cl, 1.18-11.73) comparisons underwent DC instead of definitive
Complications (pneumonia, peritonitis, intra-abdominal abscess, biliary or pancreatic fistula, bowel obstruction): OR, 0.29 (95\% Cl, 0.12-0.69) 
Table 5 Criterion validity (extent to which the utilization or conduct of damage control instead of definitive surgery for one or more indications was associated with patient outcomes) of reported indications for use of damage control surgery or damage control interventions (Continued)

\begin{tabular}{|c|c|c|c|c|}
\hline Source & Treatment or exposure group $(n)$ & Comparison group $(n)$ & $\begin{array}{l}\text { Confounding } \\
\text { factors } \\
\text { adjusted for }\end{array}$ & Outcome(s) \\
\hline $\begin{array}{l}\text { Yu et al. } \\
2009[25]\end{array}$ & $\begin{array}{l}\text { DC surgery for patients with the } \\
\text { following: preoperative temperature }< \\
35^{\circ} \mathrm{C}, \mathrm{pH}<7.25, \mathrm{PT}>16 \mathrm{~s} \text {, aPTT }>50 \mathrm{~s} \text {, } \\
\text { or systolic } \mathrm{BP}<70 \mathrm{mmHg} \text {; transfusion } \\
>10 \mathrm{U} \text { PRBCs; inability to close the } \\
\text { abdomen because of visceral edema; } \\
\text { or a predicted surgical duration }>90 \\
\text { min }(n=45)\end{array}$ & $\begin{array}{l}\text { Definitive surgery for patients with } \\
\text { these indications }(n=45)\end{array}$ & $\begin{array}{l}\text { None for all } \\
\text { comparisons }\end{array}$ & $\begin{array}{l}\text { Survival: OR, } 3.03 \text { (95\% Cl, 0.66-18.79) } \\
\text { Complications (abscesses, ARDS, } \\
\text { multiple organ failure): OR, } 0.29 \text { ( } 95 \% \\
\text { Cl, 0.099-0.80) } \\
\text { Mean ICU LOS: } 10 \text { vs. } 8 \mathrm{~d}(p=0.02) \\
\text { Mean hospital LOS: } 27 \text { vs. } 21 \mathrm{~d}(p= \\
\text { 0.01) }\end{array}$ \\
\hline $\begin{array}{l}\text { MacKenzie } \\
\text { et al. } 2004 \\
{[51]}\end{array}$ & $\begin{array}{l}\text { Laparotomy with early therapeutic } \\
\text { perihepatic packing followed by } \\
\text { angioembolization for patients with } \\
\text { AAST grade IV-V liver injuries }(n=7)^{\mathrm{e}}\end{array}$ & $\begin{array}{l}\text { Definitive laparotomy for patients } \\
\text { with AAST grade IV-V liver injuries ( } n \\
=30)^{\mathrm{e}}\end{array}$ & $\begin{array}{l}\text { None for all } \\
\text { comparisons }\end{array}$ & $\begin{array}{l}\text { Survival was } 100 \% \text { in the early packing } \\
\text { versus } 63.3 \% \text { in the definitive } \\
\text { laparotomy group ( } p=0.08) \\
\text { Complications in the early packing vs. } \\
\text { definitive laparotomy group included } \\
\text { liver necrosis (OR, } 4.88 ; 95 \% \mathrm{Cl}, 0.49- \\
41.81) \text {, sepsis (OR, } 1.75 ; 95 \% \mathrm{Cl}, 0.21- \\
12.67) \text {, abscesses (OR, } 6.75 ; 95 \% \mathrm{Cl} \text {, } \\
0.62-66.67) \text {, and bile leak (OR, } 4.38 \text {; } \\
95 \% \mathrm{Cl}, 0.56-35.95) \\
\text { Median hospital LOS: } 30 \text { vs. } 10.5 \mathrm{~d} \text { ( } p \\
\text { value NR) } \\
\text { Median ICU LOS: } 7 \text { vs. } 2 \mathrm{~d} \text { ( } p \text { value NR) }\end{array}$ \\
\hline $\begin{array}{l}\text { Asensio } \\
\text { et al. } 2004 \\
{[52]}\end{array}$ & $\begin{array}{l}\text { After implementation of a guideline } \\
\text { that suggested use of DC surgery for } \\
\text { patients with the following: transfusion } \\
>4 \mathrm{~L} \text { PRBCs or }>5 \mathrm{~L} \text { PRBCs and whole } \\
\text { blood combined; total OR fluid (PRBCs } \\
\text { and whole blood, other blood } \\
\text { products, and crystalloid) replacement } \\
>12 \mathrm{~L} \text {; operating room patient } \\
\text { temperature } \leq 34^{\circ} \mathrm{C} \text {, serum }\left[\mathrm{HCO}_{3}\right] \leq \\
15 \mathrm{mEq} / \mathrm{L} \text {, or arterial pH } \leq 7.2 ; \text { a } \\
\text { thoracic or abdominal vascular injury } \\
\text { or complex hepatic injury requiring } \\
\text { packing; those requiring ED or } \\
\text { operating room thoracotomy; or }\end{array}$ & $\begin{array}{l}\text { Before implementation of the DC } \\
\text { surgery guideline }(n=86)\end{array}$ & $\begin{array}{l}\text { None for all } \\
\text { comparisons }\end{array}$ & $\begin{array}{l}\text { Survival: OR, } 0.99 \text { ( } 95 \% \mathrm{Cl}, 0.42 \text { to } 2.42 \text { ) } \\
\text { Intra-abdominal abscesses: } \mathrm{OR}, 0.29 \\
(95 \% \mathrm{Cl}, 0.067 \text { to } 0.95) \\
\text { Abdominal fistula(e): } 0.34 \text { ( } 95 \% \mathrm{Cl} \text {, } \\
0.059 \text { to } 1.32 \text { ) } \\
\text { Extra-abdominal infection: } \mathrm{OR}, 0.34 \\
\text { ( } 95 \% \mathrm{Cl}, 0.15 \text { to } 0.77) \\
\text { Abdominal wall closure: } \mathrm{OR}, 44.93 \text { ( } 95 \% \\
\text { Cl, } 11.17 \text { to } 248.12 \text { ) } \\
\text { Mean SICU LOS: } 14.1 \text { vs. } 22.4 \mathrm{~d} \text { ( } p= \\
\text { 0.02) } \\
\text { Mean hospital LOS: } 22.9 \text { vs. } 36.8 \mathrm{~d}(p= \\
\text { 0.08) }\end{array}$ \\
\hline
\end{tabular}

Apartsin DC laparotomy for liver and

et al. 2002 retroperitoneal injuries $(n=62)$ or

[23] major small bowel injuries $(n=15)$

Carrillo DC laparotomy for patients with

et al. 1998 penetrating injuries to the iliac vessels

[58] $\quad(n=14)(11$ had combined

arteriovenous injuries to the common and external iliac vessels)

Rotondo DC laparotomy for penetrating trauma et al. 1993 patients requiring transfusion of $>10 \mathrm{U}$ [62] PRBCs before completion or termination of laparotomy with $\geq 1$ major abdominal vascular injury and $\geq$ 2 abdominal visceral injuries $(n=13)$

Carmona Therapeutic liver packing for patients et al. 1984 with intraoperative hemodynamic [67] instability after more conventional techniques of hemorrhage control (e.g., direct, Pringle maneuver, hepatic artery ligation) had failed $(n=17)$

Stone et al. DC laparotomy followed by closure of
Definitive laparotomy for liver and retroperitoneal $(n=59)$ and major small bowel injuries $(n=14)$

Definitive laparotomy for patients with this indication $(n=50)$ (13 had combined arteriovenous injuries)

Definitive laparotomy for penetrating None trauma patients with this indication $(n=9)$

Definitive surgery for patients with this indication who were similarly matched on age, mechanism of injury, and associated injuries ( $n=$ 14)

Definitive laparotomy for patients
None for both Survival for liver and retroperitoneal comparisons injuries: OR, $2.73(95 \% \mathrm{Cl}, 1.15$ to 6.60$)$ Survival for patients with major small bowel injuries: OR, 10.08 (95\% Cl, 1.44 to 80.87 )

None for both Survival overall: OR, 0.71 (95\% Cl, 0.16comparisons 3.70)

Survival for patients with combined injuries: OR, 6.25 (95\% Cl, 0.50-324.50)

Survival: OR, 26.67 (95\% Cl, 1.841296.95)

None for both Survival: OR, 2.05 (95\% Cl, 0.19-27.79) comparisons Infection: OR, 0.75 (95\% Cl, 0.13-4.43)

None for all Survival: OR, $23.83(95 \%$ Cl, 2.22- 
Table 5 Criterion validity (extent to which the utilization or conduct of damage control instead of definitive surgery for one or more indications was associated with patient outcomes) of reported indications for use of damage control surgery or damage control interventions (Continued)

\begin{tabular}{|c|c|c|c|c|}
\hline Source & Treatment or exposure group $(n)$ & Comparison group $(n)$ & $\begin{array}{l}\text { Confounding } \\
\text { factors } \\
\text { adjusted for }\end{array}$ & Outcome(s) \\
\hline $1983[68]$ & $\begin{array}{l}\text { the abdomen under tension for } \\
\text { patients who develop coagulopathy } \\
\text { during operation ( } n=17)\end{array}$ & $\begin{array}{l}\text { who develop coagulopathy during } \\
\text { operation }(n=14)\end{array}$ & comparisons & $\begin{array}{l}\text { 1102.13) } \\
\text { All survivors (including } n=12 \\
\text { managed with DC and closure of the } \\
\text { abdomen under tension and } n=1 \\
\text { managed with definitive laparotomy) } \\
\text { developed complications, including } \\
\text { wound infections (100\% of those } \\
\text { managed with DC), intra-abdominal } \\
\text { abscesses ( } 69.2 \% \text { of the } 13) \text {, and intes- } \\
\text { tinal fistulae ( } 15.4 \% \text { of the } 13 \text { ) }\end{array}$ \\
\hline
\end{tabular}

Where AIS indicates Abbreviated Injury Scale; BD, base deficit; BP, blood pressure; $\mathrm{Cl}$, confidence interval; d, days; $\mathrm{DC}$, damage control; ED, Emergency Department; GI, gastrointestinal; LOS, length of stay; MOI, mechanism of injury; NR, not reported; OR, odds ratio; PRBC, packed red blood cells; SICU, surgical intensive care unit; SSI, surgical site infection; and TBI, traumatic brain injury

${ }^{a}$ Variables reported to be used to generate propensity scores for matching between the groups included ISS; age; gender; mechanism of injury; ED systolic BP; ED Glasgow Coma Scale score; ED BD; ED activated clotting time; ED percent lysis at 30 min; ED PRBC transfusion; time in ED; final operating room temperature; final OR systolic BP; total operating room PRBCs; final operating room $\mathrm{pH}$; final operating room BD; and final operating room lactic acid

${ }^{b}$ Where minor deviations included departures deemed not clinically significant; moderate deviations included care, which although departures were present, mostly followed protocol; and major deviations included those that did not meet the standards outlined in the protocol.

'Variables reported to be entered into the logistic regression model included age; gender; injury type; time from injury to hospitalization; PRBCs transfused before hospitalization; ISS; Glasgow Coma Scale score; shock; baseline hemoglobin, creatinine and activated PTT; country; and patients who did not require DC for both outcome comparisons

${ }^{d}$ Variables reported to be entered into logistic and linear regression models included age; gender; mechanism of injury; head injury; major extremity injury; combined abdominal injury; ISS; presenting vitals; BD; and need for colon resection

e In this study, 15 of the patients in the definitive laparotomy group were reported to ultimately need abdominal packing after conventional hepatic injury repair techniques. Moreover, 1 patient in the early therapeutic packing group received angiography before laparotomy

reduced survival in patients managed with definitive surgery [an elevated preoperative BD [57] and DC surgery [a preoperative $\mathrm{pH}<7.20$ [47]. This last finding suggests that although several measures of physiological compromise have been assessed by both international experts and practicing surgeons to be highly appropriate indications for use of DC $[3,16,17]$, some data suggest that there may be a point beyond which physiologic derangements have progressed too far for DC surgery to improve survival [49].

We identified only six indications that had evidence to support that their utilization or the conduct of DC surgery may improve patient survival. These indications represent those with the most evidence to support their use and include the finding of hypothermia or acidosis, development of a coagulopathy during operation, or the identification of two injury patterns that preclude expedient definitive repair (combined abdominal vascular and pancreas gunshot injuries and $\geq 1$ major abdominal vascular and $\geq 2$ abdominal visceral injuries in patients who have received $>10 \mathrm{U}$ PRBCs) $[44,62,68]$. However, as these were observational studies and operative profile (i.e., DC versus definitive surgery) was not randomly assigned, there were likely other, unmeasured reasons why surgeons chose to perform DC in these studies that are related to the risk of future outcomes (i.e., the studies were likely confounded by indication) [73].
Those indications with evidence suggesting that they may be associated with poor outcomes or that outcomes may be improved with use of DC surgery represent targets for focused future research efforts (Table 6). As studies cannot deliver an unbiased and meaningful assessment of validity if the type of operative procedure varies in relation to the indication of interest [28], subsequent study of indications for DC surgery must compare the outcomes of performing DC versus definitive surgery in patients with well-defined indications. This should begin with prospective cohort studies designed to estimate the causal effects of DC surgery by controlling for confounding by indication using multivariate adjustment, propensity scores, or other techniques [73]. A randomized controlled trial would provide the least biased estimates of the benefit/harm ratio of DC compared to definitive surgery in different clinical circumstances. Initial trials should randomize patients to DC or definitive surgery in those clinical circumstances with the greatest uncertainty about the potential role of DC surgery (i.e., those indications listed in Table 6 that have no or equivalent evidence of content, construct, and criterion validity). While the above studies are being designed and conducted, creation of a list of DC consensus indications may allow for the conduct of quality improvement or knowledge translation interventions to decrease overutilization of DC in trauma patients. 
Table 6 Narrative (vote counting) synthesis of evidence for indications for use of damage control surgery in civilian trauma patients

\begin{tabular}{|c|c|c|c|c|c|}
\hline \multirow{2}{*}{$\begin{array}{l}\text { Indication Category } \\
\text { Subcategory } \\
\text { Unique Indication }\end{array}$} & \multicolumn{2}{|c|}{ Content Validity } & \multicolumn{2}{|c|}{ Construct Validity } & \multirow{2}{*}{$\begin{array}{c}\text { Criterion } \\
\text { Validity }\end{array}$} \\
\hline & $\begin{array}{l}\text { Surgeon } \\
\text { Surveys }\end{array}$ & $\begin{array}{l}\text { Cohort } \\
\text { Studies }\end{array}$ & $\begin{array}{c}\text { Predicts } \\
\text { Coagulopathy }\end{array}$ & $\begin{array}{l}\text { Predicts Reduced } \\
\text { Survival }\end{array}$ & \\
\hline \multicolumn{6}{|l|}{ Preoperative indications } \\
\hline \multicolumn{6}{|l|}{ Injury pattern } \\
\hline $\begin{array}{l}\text { Upper quadrant abdominal GSW with a horizontal shift trajectory (e.g., } \\
\text { from the RUQ to the LUQ) and a systolic } \mathrm{BP}<105 \mathrm{mmHg} \text { [55] }\end{array}$ & 0 & $2+$ & 0 & 0 & 0 \\
\hline $\begin{array}{l}\text { RUQ wound with a bullet retained in the same quadrant and a systolic } \\
\text { BP }<90 \mathrm{mmHg}[55]\end{array}$ & 0 & $2+$ & 0 & 0 & 0 \\
\hline \multicolumn{6}{|l|}{ Overall injury burden } \\
\hline High ISS score $[57,61]$ & 0 & 0 & 0 & $2+$ & 0 \\
\hline \multicolumn{6}{|l|}{ Volume and/or type of resuscitation provided } \\
\hline Transfusion of a large volume of PRBCs $[24,25,61]$ & 0 & 0 & 0 & $+/-$ & $+/-$ \\
\hline \multicolumn{6}{|l|}{ Degree of physiologic insult } \\
\hline Systolic BP $<70 \mathrm{mmHg}[25]$ & 0 & 0 & 0 & 0 & $+/-$ \\
\hline Prolonged duration of hypotension [61] & 0 & 0 & 0 & $+/-$ & 0 \\
\hline Systolic BP $<90 \mathrm{mmHg}$ on admission and grade III-V liver injury [46] & 0 & $+/-$ & 0 & 0 & 0 \\
\hline Hypothermia $[24,25,47,49,57]$ & 0 & 0 & 0 & $2+$ & $+/-$ \\
\hline Acidosis $(\uparrow \mathrm{BD}$ or decreased $\mathrm{pH})[24,25,47,49,57,61]$ & 0 & 0 & 0 & + & $+/-$ \\
\hline Thrombocytopenia [61] & 0 & 0 & 0 & 0 & 0 \\
\hline Laboratory-confirmed coagulopathy ( $\uparrow$ PT and/or PTT) $[24,25,61,63]$ & 0 & 0 & 0 & $+/-$ & $+/-$ \\
\hline \multicolumn{6}{|l|}{ Intraoperative indications } \\
\hline \multicolumn{6}{|l|}{ Injury pattern identified during operation } \\
\hline Thoracic or abdominal vascular injury $[15,52]$ & 0 & + & 0 & 0 & $+/-$ \\
\hline $\begin{array}{l}\text { Unstable patients with combined abdominal vascular and pancreas } \\
\text { gunshot injuries [44] }\end{array}$ & 0 & 0 & 0 & $3+$ & + \\
\hline $\begin{array}{l}\text { Penetrating trauma patients requiring }>10 \text { U PRBCs with } \geq 1 \text { major } \\
\text { abdominal vascular injury and } \geq 2 \text { abdominal visceral injuries }[62]\end{array}$ & 0 & 0 & 0 & 0 & + \\
\hline Iliac vessel injury [58] & 0 & 0 & 0 & 0 & $+/-$ \\
\hline And prolonged duration of hypotension [58] & 0 & 0 & 0 & $+/-$ & 0 \\
\hline And initial temperature $<34^{\circ} \mathrm{C}[59]$ & 0 & 0 & 0 & $+/-$ & 0 \\
\hline And final temperature $<35^{\circ} \mathrm{C}[59]$ & 0 & 0 & 0 & + & 0 \\
\hline And initial $\mathrm{BD}>15 \mathrm{mEq} / \mathrm{L}$ or $\mathrm{pH}<7.1[59]$ & 0 & 0 & 0 & + & 0 \\
\hline And final $\mathrm{BD}>6 \mathrm{mEq} / \mathrm{L}$ or $\mathrm{pH}<7.3[59]$ & 0 & 0 & 0 & + & 0 \\
\hline And final PT $>20 \mathrm{sec}$ or PTT $>70 \mathrm{sec}[58]$ & 0 & 0 & 0 & $+/-$ & 0 \\
\hline $\begin{array}{l}\text { And shock, hypothermia, acidosis, or coagulopathy (intraoperative } \\
\text { timing of measurement NR) [54] }\end{array}$ & 0 & 0 & 0 & $+/-$ & 0 \\
\hline $\begin{array}{l}\text { AAST grade IV-V liver injuries or complex liver injuries requiring } \\
\text { packing }[46,51,52]\end{array}$ & 0 & $+/-$ & 0 & 0 & $+/-$ \\
\hline $\begin{array}{l}\text { Inability to control hepatic hemorrhage with conventional techniques of } \\
\text { hemorrhage control }[38,67]\end{array}$ & 0 & 0 & 0 & 0 & 0 \\
\hline Combined AAST grade III-V liver and IV-V spleen injury [46] & 0 & + & 0 & 0 & 0 \\
\hline Full-thickness duodenal lacerations [45] & 0 & 0 & 0 & 0 & $+/-$ \\
\hline Complex penetrating AAST grade II-IV duodenal injuries [40] & 0 & 0 & 0 & 0 & $+/-$ \\
\hline $\begin{array}{l}\text { Severe pancreaticoduodenal trauma requiring } \\
\text { pancreaticoduodenectomy [42] }\end{array}$ & 0 & 0 & 0 & 0 & $+/-$ \\
\hline Multiple intra-abdominal injuries [72] & No & 0 & 0 & 0 & 0 \\
\hline \multicolumn{6}{|l|}{ Volume, rate, and/or type of resuscitation provided } \\
\hline $\begin{array}{l}\text { Transfusion of a large volume of PRBCs (e.g., }>10 \mathrm{U} \text { or } 4 \mathrm{~L} \text { ) }[24,25 \text {, } \\
52,56,65,72]\end{array}$ & No & 0 & 0 & $+/-$ & $+/-$ \\
\hline $\begin{array}{l}\text { Administration of }>5 \mathrm{~L} \text { PRBCs and whole blood combined or }>12 \mathrm{~L} \\
\text { PRBCs or whole blood, other blood products, and crystalloids }[52,56]\end{array}$ & 0 & 0 & 0 & $+/-$ & $+/-$ \\
\hline Requirement for rapid PRBC transfusion rates and acidosis [65] & 0 & 0 & 0 & $+/-$ & 0 \\
\hline
\end{tabular}


Table 6 Narrative (vote counting) synthesis of evidence for indications for use of damage control surgery in civilian trauma patients (Continued)

\begin{tabular}{|c|c|c|c|c|c|}
\hline \multicolumn{6}{|l|}{ Degree of physiologic insult } \\
\hline $\begin{array}{l}\text { Systolic BP }<90 \mathrm{mmHg} \text { at the start of surgery or intraoperative } \\
\text { hemodynamic instability }[38,48]\end{array}$ & 0 & 0 & 0 & $+/-$ & 0 \\
\hline Hypothermia $[48,52,56,72]$ & No & 0 & 0 & $+/-$ & $+/-$ \\
\hline Acidosis (serum $\left.\left[\mathrm{HCO}_{3}-\right] \leq 15 \mathrm{mEq}\right)[48,52,56]$ & 0 & 0 & 0 & $+/-$ & $+/-$ \\
\hline Acidosis $(\mathrm{BD}>7.5 \mathrm{mEq} / \mathrm{L})[48]$ & 0 & 0 & 0 & $+/-$ & 0 \\
\hline Acidosis $(\mathrm{pH}<7.2 / 7.3)[52,56,72]$ & No & 0 & 0 & $+/-$ & $+/-$ \\
\hline $\begin{array}{l}\text { Systolic } \mathrm{BP}<90 \mathrm{mmHg}, \mathrm{BD}>7.5 \mathrm{mEq} / \mathrm{L}, \text { and temperature }<35.5^{\circ} \mathrm{C} \text { at } \\
\text { the start of surgery [48] }\end{array}$ & 0 & 0 & 0 & $+/-$ & 0 \\
\hline Elevated ACT [53] & 0 & 0 & $+/-$ & 0 & 0 \\
\hline Coagulopathy $[24,25,52,68,72]$ & No & 0 & 0 & 0 & + \\
\hline \multicolumn{6}{|l|}{ Need for staged abdominal wall reconstruction } \\
\hline $\begin{array}{l}\text { Fecal intra-abdominal contamination or excessive intra-abdominal } \\
\text { contamination }[38,72]\end{array}$ & No & 0 & 0 & 0 & 0 \\
\hline $\begin{array}{l}\text { Planned reoperation (e.g., to remove intra-abdominal packs or for a } \\
\text { second-look) }[38,70,72]\end{array}$ & Yes & 0 & 0 & 0 & 0 \\
\hline Abdominal visceral edema $[69,70]$ & No & 0 & 0 & 0 & 0 \\
\hline Massive abdominal visceral edema [72] & Yes & 0 & 0 & 0 & 0 \\
\hline Inability to close the abdominal fascia $[69,70]$ & Yes & 0 & 0 & 0 & 0 \\
\hline $\begin{array}{l}\text { Signs of abdominal compartment syndrome develop during attempted } \\
\text { fascial closure (e.g., pulmonary deterioration or hemodynamic } \\
\text { instability) }[70,72]\end{array}$ & Yes & 0 & 0 & 0 & 0 \\
\hline To expedite postoperative care or intervention [38] & No & 0 & 0 & 0 & 0 \\
\hline \multicolumn{6}{|c|}{ Pre- or intraoperative indications (or indications for which the setting was unclear or not specified) } \\
\hline \multicolumn{6}{|c|}{ Overall injury burden } \\
\hline Multiple trauma and AAST grade III-V liver injury [46] & 0 & $+/-$ & 0 & 0 & 0 \\
\hline \multicolumn{6}{|l|}{ Volume and/or type of resuscitation provided } \\
\hline Transfusion $>10$ U PRBCs and AAST grade III-V liver injury [46] & 0 & $+/-$ & 0 & 0 & 0 \\
\hline Transfusion $>15$ U PRBCs [66] & 0 & 0 & $+/-$ & 0 & 0 \\
\hline Transfusion of a large volume of PRBCs, FFP, or fluids [41] & 0 & $+/-$ & 0 & 0 & 0 \\
\hline $\begin{array}{l}\text { Transfusion }>10 \mathrm{U} \text { PRBCs and ISS }>25 \text { or lowest temperature }<34^{\circ} \mathrm{C} \\
{[50,60]^{*}}\end{array}$ & 0 & 0 & $3+$ & 0 & 0 \\
\hline $\begin{array}{l}\text { Transfusion }>10 \text { U PRBCs and systolic } \mathrm{BP}<70 \mathrm{mmHg} \text { or lowest } \mathrm{pH} \\
<7.1[50,60]^{*}\end{array}$ & 0 & 0 & $+/-$ & 0 & 0 \\
\hline A PRBC transfusion volume that exceeds the CAT [39] & 0 & + & $+/-$ & 0 & 0 \\
\hline $\begin{array}{l}\text { The number of times the PRBC transfusion volume exceeds the CAT } \\
\text { [39] }\end{array}$ & 0 & + & $+/-$ & 0 & 0 \\
\hline \multicolumn{6}{|l|}{ Degree of physiologic insult } \\
\hline Hypothermia [43, 63] & 0 & 0 & 0 & $+/-$ & $3+$ \\
\hline Acidosis ( $\uparrow$ BD) $[41,64]$ & 0 & $+/-$ & $+/-$ & + & 0 \\
\hline Acidosis ( $\uparrow$ lactate) [41, 43] & 0 & $+/-$ & 0 & 0 & $3+$ \\
\hline Acidosis (decreased pH) $[43,63]$ & 0 & 0 & 0 & $+/-$ & $3+$ \\
\hline \multicolumn{6}{|l|}{ Miscellaneous } \\
\hline $\begin{array}{l}4-5 \text { or } 2-3 \text { versus } 0-1 \text { of transfusion } \geq 10 \text { U PRBCs, lowest ED or } \\
\text { intraoperative temperature } \leq 33^{\circ} \mathrm{C}, \mathrm{pH} \leq 7.18, \text { ED PT } \geq 16 \mathrm{sec} \text {, or ED } \\
\text { PTT } \geq 50 \mathrm{sec}\end{array}$ & 0 & 0 & 0 & $+/-$ & 0 \\
\hline
\end{tabular}

Where AAST indicates American Association for the Surgery of Trauma; ACT, activated coagulation time; BP, blood pressure; CAT, critical administration threshold ( $\geq 3$ units of packed red blood cells administered in $1 \mathrm{~h}$ of the first $24 \mathrm{~h}$ of injury); DC, conduct of damage control surgery; GSW, gunshot wound; LUQ, left upper quadrant; NR, not reported; PRBCs, packed red blood cells; and RUQ, right upper quadrant.

In one of these studies, temperature $<34^{\circ} \mathrm{C}$ or $\mathrm{pH}<7.1$ was stated to be the lowest value in the first $24 \mathrm{~h}$ whereas in the other it was the value measured in the emergency department.

\section{* Key to Color Coding of Evidence.}

$0 \quad$ Not evaluated in the included studies

No $\quad$ No evidence of content validity in surveys $(<50 \%$ of respondent surgeons across the included cross-sectional surveys indicated that they would perform TAC)

Yes Content validity in surveys $(\geq 50 \%$ of respondent surgeons of respondent surgeons across the included cross-sectional surveys indicated that they would perform TAC)

+/- Inconclusive (no evidence or a low to moderate association in the setting of a high amount of bias in at least one quality domain)

$+\quad$ Low evidence (a strong association in the setting of a high amount of bias in only one quality domain)

$2+\quad$ Moderate evidence (low to moderate association in the setting of a moderate amount of bias in one or more quality domains)

Strong evidence (a low to moderate association with a low amount of bias in all quality domains or a strong statistical association with a moderate amount of bias in one or more quality domains)

*When multiple studies evaluated the indication, the studies with the lowest risk of bias were used for the validity and outcomes assessment above. 
Collectively, the above data suggest that there exists little evidence to support the high DC surgery utilization rates reported by many level 1 trauma centers. In a recently reported post-hoc analysis of the PROPPR randomized trial, DC was used among $33 \%$ to $83 \%$ of patients requiring urgent laparotomy across 12 of the participating institutions [15]. Interestingly, although there was no significant adjusted mortality difference between these centers, the unadjusted risk of sepsis and ventilator-associated pneumonia was higher among those treated with DC laparotomy, suggesting that decreasing use of DC among individual trauma centers may not influence mortality, but may decrease associated morbidity [15]. These findings are supported by two studies included in this systematic review, which both reported that use of DC laparotomy among lower risk cohorts of injured patients was associated with increased complications and longer hospital lengths of stay [14, 38]. As these findings may have been influenced by differences in patient characteristics between groups in the above studies, they should be interpreted cautiously and confirmed by future studies.

This study has potential limitations. First, some of the indications evaluated in this systematic review were dependent on a single clinical finding. While experts and practicing surgeons have previously reported that they would conduct DC surgery when encountered with certain single clinical findings (e.g., massive destruction of the pancreatic head) $[3,16,17]$, surgeons frequently decide to conduct DC surgery only after considering multiple clinical findings simultaneously (Table 6). Second, many of the indications assessed in the studies included in this systematic review included static physiologic or laboratory values as decision thresholds. As surveys have suggested that practicing surgeons believe that unless physiologic derangements are persistent during operation that it is likely safe to attempt a definitive trauma operation, arguably more important than any static value are the trends in these values during the early resuscitation and operative phases. Third, as our systematic review included studies of patients mostly undergoing DC surgery for torso trauma, our findings likely cannot be generalized to patients undergoing emergency general, orthopedic, or military surgery. Finally, although most of the studies included in this systematic review were reported after the year 2000, our findings must be interpreted within the context of the time range over which they were published (1983-2017). Recent changes in resuscitation practices have likely resulted in a decrease in the frequency of the need for open abdominal management because of post-injury abdominal visceral swelling [74-76]. Moreover, some have suggested that novel resuscitation strategies may potentially prevent or treat the lethal triad, which would suggest that the threshold used to select patients presenting with deranged physiology for DC surgery could potentially rise in the future pending the results of ongoing research [77].

\section{Conclusions}

This systematic review identified a large number of indications for use of DC surgery in civilian trauma patients. Few had evidence of validity or that they were associated with improved outcomes when utilized or when DC was performed instead of definitive surgery. Appropriately designed prospective observational studies comparing the benefit-risk profile associated with conduct of DC versus definitive surgery for patients resuscitated according to currently accepted standards and treated with the indications identified in this study are therefore urgently required. In the interim, our findings support that DC should be used with respect for the uncertainty regarding its effectiveness, and only in those circumstances where definitive surgery cannot be entertained.

\section{Supplementary Information}

The online version contains supplementary material available at https://doi. org/10.1186/s13017-021-00352-5.

Additional file 1. Supplemental Digital Content 1. Operationalized and Expanded QUIPS Guidelines for Assessing Risk of Bias in Included Studies. .docx file type.

Additional file 2. Supplemental Digital Content 2. Characteristics of the Three Cross-Sectional Studies Included in the Systematic Review. .docx file type.

Additional file 3. Supplemental Digital Content 3. Risk of Bias Assessment for the 35 Included Cohort Studies. .docx file type.

Additional file 4. Supplemental Digital Content 4. Standards for Use and Reporting of Logistic Regression in the Medical Literature.

Additional file 5. Supplemental Digital Content 5. Risk of Bias Assessment for the Three Included Cross-Sectional Studies.

\section{Abbreviations}

AAST: American Association for the Surgery of Trauma; BP: Blood pressure; $\mathrm{Cl}$ : Confidence interval; DC: Damage control; EAST: Eastern Association for the Surgery of Trauma; ED: Emergency department; Gl: Gastrointestinal; HR: Hazard ratio; ICU: Intensive care unit; ISS: Injury Severity Scale; OR: Odds ratio; PRBC: Packed red blood cells; PROPPR: Pragmatic, Randomized Optimal Platelet and Plasma Ratios; TAC: Temporary abdominal closure; WTA: Western Trauma Association

\section{Acknowledgments}

Dr. Roberts had full access to all data in the study and takes responsibility for the integrity of the data and the accuracy of the data analyses. We thank Helen Lee Robertson, MLIS for assisting with the design of the search strategy and the staff of the University of Calgary Health Sciences Library for obtaining copies of articles identified throughout the conduct of the study. Dr. Roberts is supported by an Alberta Innovates-Health Solutions (AIHS) Clinician Fellowship Award, a Knowledge Translation (KT) Canada Strategic Training in Health Research Fellowship, a KT Canada Research Stipend, and funding from the Canadian Institutes of Health Research (CIHR). Dr. Stelfox is supported by an Embedded Clinician Researcher Award from CIHR. Members of the Indications for Trauma Damage Control Surgery International Study Group include Karim Brohi, MD (Centre for Trauma Sciences, Blizard Institute, Queen Mary University of London, United Kingdom); Scott D'Amours, MD (Department of Surgery, University of New South Wales, Liverpool Hospital, Australia); Timothy C. Fabian, MD (Department of Surgery, University of Tennessee Health Science Center, 
Memphis, Tennessee, United States of America); Kenji Inaba, MD (Department of Surgery, University of Southern California, Los Angeles, California, United States of America); Ari K. Leppäniemi, MD, PhD (Department of Surgery, Helsinki University Central Hospital, Helsinki, Finland); Ernest E. Moore, MD (Department of Surgery, University of Colorado, Denver, Colorado, United States of America); Pradeep H. Navsaria, MBChB, MMed (Surg) (Trauma Centre, Department of Surgery, Groote Schuur Hospital, University of Cape Town, Cape Town, South Africa); Andrew J. Nicol, MBChB, PhD (Trauma Centre, Department of Surgery, Groote Schuur Hospital, University of Cape Town, Cape Town, South Africa); and Neil Parry, MD (Divisions of General Surgery and Critical Care, Departments of Surgery and Medicine, Schulich School of Medicine and Dentistry, Western University and the Trauma Program, London Health Sciences Centre, London, Ontario, Canada)

\section{Authors' contributions}

Study concept and design: DJR. Acquistion of study funding: DJR, DAZ, AWK, HTS. Creation of study protocol: DJR, NB, DAZ, AWK, CGB, PDF, HTS. Literature search: DJR, NB. Extraction and charting of data: DJR, NB. Analysis of data: DJR, NB. Interpretation of data analyses: DJR, NB, DAZ, AWK, CGB, PDF, HTS. Drafting of the manuscript: DJR. Critical revision of the manuscript: DJR, NB, DAZ, AWK, CGB, PDF, HTS. Study supervision: DJR, HTS. All authors read and approved the final manuscript.

\section{Funding}

This study was supported by a Knowledge Translation (KT) Canada Research Stipend, an Alberta Innovates-Health Solutions Clinician Fellowship Award $(\mathrm{AlHS})$, and funding from the Canadian Institutes of Health Research (CIHR). These funders had no role in the design or conduct of the study; collection, management, analysis, or interpretation of the data; or preparation, review, or approval of the resultant manuscript.

\section{Availability of data and materials}

All data included and analyzed in the study have previously been published.

\section{Ethics approval and consent to participate}

Not applicable.

\section{Consent for publication}

Not applicable.

\section{Competing interests}

The authors have no conflicts of interest to declare.

\section{Author details}

'Division of Vascular and Endovascular Surgery, University of Ottawa, Ottawa, ON, Canada. ${ }^{2}$ Clinical Epidemiology Program, Ottawa Hospital Research Institute, The Ottawa Hospital, Ottawa, ON, Canada. ${ }^{3}$ Nuffield Department of Primary Care Health Sciences, University of Oxford, Oxford, UK. ${ }^{4}$ Division of Critical Care Medicine, University of Alberta, Edmonton, AB, Canada. ${ }^{5}$ Department of Surgery, University of Calgary, Calgary, AB, Canada. ${ }^{6}$ Department of Critical Care Medicine, University of Calgary and Alberta Health Services, Calgary, AB, Canada. ${ }^{7}$ The Regional Trauma Program, University of Calgary and the Foothills Medical Center, Calgary, AB, Canada. ${ }^{8}$ Department of Oncology, University of Calgary and the Foothills Medical Centre, Calgary, AB, Canada. ${ }^{9}$ Alberta Health Sciences Research-Research Analytics, University of Calgary and the Foothills Medical Centre, Calgary, AB, Canada. ${ }^{10} \mathrm{O}$ 'Brien Institute for Public Health, University of Calgary, Calgary, $A B$, Canada. ${ }^{11}$ Department of Community Health Sciences, University of Calgary, Calgary, AB, Canada.

\section{Received: 28 November 2020 Accepted: 11 February 2021}

\section{Published online: 11 March 2021}

\section{References}

1. Roberts DJ, Zygun DA, Kirkpatrick AW, et al. A protocol for a scoping and qualitative study to identify and evaluate indications for damage control surgery and damage control interventions in civilian trauma patients. BMJ Open. 2014;4(7):e005634.

2. Roberts DJ, Bobrovitz N, Zygun DA, et al. Indications for use of damage control surgery and damage control interventions in civilian trauma patients: a scoping review. J Trauma Acute Care Surg. 2015; 78(6):1187-96

3. Roberts DJ, Bobrovitz N, Zygun DA, et al. Indications for use of damage control surgery in civilian trauma patients: a content analysis and expert appropriateness rating study. Ann Surg. 2016;263(5):1018-27.

4. Roberts DJ, Ball CG, Feliciano DV, et al. History of the innovation of damage control for management of trauma patients: 1902-2016. Ann Surg. 2017; 265(5):1034-44.

5. Damage control: Trauma medicine has learned lessons from the battlefield: Civilian doctors are saving more lives after terrorist attacks by copying their military peers. 2017. https://http://www.economist.com/news/international/ 21730145-civilian-doctors-are-saving-more-lives-after-terrorist-attackscopying-their-military.

6. Shapiro MB, Jenkins DH, Schwab CW, et al. Damage control: collective review. J Trauma. 2000:49(5):969-78.

7. Chovanes J, Cannon JW, Nunez TC. The evolution of damage control surgery. Surg Clin N Am. 2012;92(4):859-75 vii-viii.

8. Brenner M, Bochicchio G, Bochicchio K, et al. Long-term impact of damage control laparotomy: a prospective study. Arch Surg. 2011;146(4):395-9.

9. Miller RS, Morris JA Jr, Diaz JJ Jr, et al. Complications after 344 damagecontrol open celiotomies. J Trauma. 2005;59(6):1365-71 discussion 71-4.

10. Dubose JJ, Scalea TM, Holcomb JB, et al. Open abdominal management after damage-control laparotomy for trauma: a prospective observational American Association for the Surgery of Trauma multicenter study. J Trauma Acute Care Surg. 2013;74(1):113-20 discussion 1120-2.

11. Montalvo JA, Acosta JA, Rodriguez P, et al. Surgical complications and causes of death in trauma patients that require temporary abdominal closure. Am Surg. 2005;71(3):219-24.

12. Higa G, Friese R, O'Keeffe T, et al. Damage control laparotomy: a vital tool once overused. J Trauma. 2010;69(1):53-9.

13. Hatch QM, Osterhout LM, Podbielski J, et al. Impact of closure at the first take back: complication burden and potential overutilization of damage control laparotomy. J Trauma. 2011;71(6):1503-11.

14. Martin MJ, Hatch Q, Cotton B, et al. The use of temporary abdominal closure in low-risk trauma patients: helpful or harmful? J Trauma Acute Care Surg. 2012;72(3):601-6 discussion 06-8.

15. Watson JJ, Nielsen J, Hart K, et al. Damage control laparotomy utilization rates are highly variable among Level I trauma centers: Pragmatic, randomized optimal platelet and plasma ratios findings. J Trauma Acute Care Surg. 2017:82(3):481-8.

16. Roberts DJ, Bobrovitz N, Zygun DA, et al. Indications for use of thoracic, abdominal, pelvic, and vascular damage control interventions in trauma patients: A content analysis and expert appropriateness rating study. J Trauma Acute Care Surg. 2015;79(4):568-79.

17. Roberts DJ, Zygun DA, Faris PD, et al. Opinions of practicing surgeons on the appropriateness of published indications for use of damage control surgery in trauma patients: an international cross-sectional survey. J Am Coll Surg. 2016;223(3):515-29

18. Roberts DJ, Stelfox HT, Moore LJ, et al. Accuracy of published indications for predicting use of damage control during laparotomy for trauma. J Surg Res. 2020;248:45-55.

19. Liberati A, Altman DG, Tetzlaff J, et al. The PRISMA statement for reporting systematic reviews and meta-analyses of studies that evaluate health care interventions: explanation and elaboration. Ann Intern Med. 2009;151(4): W65-94.

20. Stroup DF, Berlin JA, Morton SC, et al. Meta-analysis of observational studies in epidemiology: a proposal for reporting. Meta-analysis Of Observational Studies in Epidemiology (MOOSE) group. JAMA. 2000; 283(15):2008-12.

21. A Dictionary of Epidemiology 5th Edition. Oxford, U.K.: Oxford University Press, 2008.

22. Stelfox HT, Straus SE, Nathens A, et al. Evidence for quality indicators to evaluate adult trauma care: a systematic review. Crit Care Med. 2011;39(4): 846-59.

23. Apartsin KA, Stifutkin AV, Rasulov Rl, et al. [Staged correction of surgical pathology of the stomach ("Damage Control") in conditions of decompensated hypovolemic shock]. Vestnik khirurgii imeni I. I. Grekova. 2002;161(2):102-5.

24. Liu QW, Zhou BJ, Qin HX, et al. [Application of damage control surgery for severe abdominal trauma]. Zhonghua wei chang wai ke za zhi $=$. Chinese Journal of Gastrointestinal Surgery. 2011;14(7):506-8. 
25. Yu BQ, Hu HB, Li M, et al. [Strategy and analysis of early management on ninety multiple trauma patients]. Zhonghua wai ke za zhi [Chinese Journal of Surgery]. 2009;47(20):1550-2.

26. Hayden JA, Cote P, Bombardier C. Evaluation of the quality of prognosis studies in systematic reviews. Ann Intern Med. 2006;144(6):427-37.

27. Hayden JA, van der Windt DA, Cartwright $J \mathrm{~L}$, et al. Assessing bias in studies of prognostic factors. Ann Intern Med. 2013;158(4):280-6.

28. Altman DG. Systematic reviews of evaluations of prognostic variables. BMJ. 2001;323(7306):224-8.

29. Burns KE, Duffett $M$, Kho ME, et al. A guide for the design and conduct of self-administered surveys of clinicians. CMAJ. 2008;179(3):245-52.

30. Bagley SC, White $\mathrm{H}$, Golomb BA. Logistic regression in the medical literature: standards for use and reporting, with particular attention to one medical domain. J Clin Epidemiol. 2001;54(10):979-85.

31. Moss M, Wellman DA, Cotsonis GA. An appraisal of multivariable logistic models in the pulmonary and critical care literature. Chest. 2003;123(3):923-8.

32. Hsieh HF, Shannon SE. Three approaches to qualitative content analysis. Qual Health Res. 2005;15(9):1277-88.

33. Popay J, Roberts H, Sowden A, et al. Guidance on the Conduct of Narrative Synthesis in Systematic Reviews. Lancaster, PA: ESRC Methods Programme; 2006.

34. Landis JR, Koch GG. The measurement of observer agreement for categorical data. Biometrics. 1977;33(1):159-74.

35. DerSimonian R, Laird N. Meta-analysis in clinical trials. Control Clin Trials. 1986;7(3):177-88.

36. Higgins JP, Thompson SG, Deeks JJ, et al. Measuring inconsistency in metaanalyses. BMJ. 2003;327(7414):557-60.

37. Higgins JP, Thompson SG. Quantifying heterogeneity in a meta-analysis. Stat Med. 2002;21(11):1539-58.

38. Harvin JA, Wray CJ, Steward J, et al. Control the damage: morbidity and mortality after emergent trauma laparotomy. Am J Surg. 2016; 212(1):34-9.

39. Savage SA, Sumislawski JJ, Croce MA, et al. Using critical administration thresholds to predict abbreviated laparotomy. J Trauma Acute Care Surg. 2014:77(4):599-603.

40. Ordonez C, Garcia A, Parra MW, et al. Complex penetrating duodenal injuries: less is better. J Trauma Acute Care Surg. 2014;76(5):1177-83.

41. Mahmood I, Mahmood S, Parchani A, et al. Intra-abdominal hypertension in the current era of modern trauma resuscitation. ANZ J Surg. 2014;84(3):166-71.

42. Thompson CM, Shalhub S, DeBoard ZM, et al. Revisiting the pancreaticoduodenectomy for trauma: a single institution's experience. J Trauma Acute Care Surg. 2013;75(2):225-8.

43. Rice TW, Morris S, Tortella BJ, et al. Deviations from evidence-based clinical management guidelines increase mortality in critically injured trauma patients*. Crit Care Med. 2012;40(3):778-86.

44. Chinnery GE, Krige JE, Kotze UK, et al. Surgical management and outcome of civilian gunshot injuries to the pancreas. Br J Surg. 2012; 99(Suppl 1):140-8

45. Mayberry J, Fabricant L, Anton A, et al. Management of full-thickness duodenal laceration in the damage control era: evolution to primary repair without diversion or decompression. Am Surg. 2011; 77(6):681-5

46. Leppaniemi AK, Mentula PJ, Streng MH, et al. Severe hepatic trauma: nonoperative management, definitive repair, or damage control surgery? World J Surg. 2011;35(12):2643-9.

47. Timmermans J, Nicol A, Kairinos N, et al. Predicting mortality in damage control surgery for major abdominal trauma. South Afr J Surg. 2010;48(1):6-9.

48. Matsumoto H, Mashiko K, Sakamoto Y, et al. A new look at criteria for damage control surgery. Journal of Nippon Medical School =. Nippon Ika Daigaku zasshi. 2010;77(1):13-20.

49. Kairinos N, Hayes PM, Nicol AJ, et al. Avoiding futile damage control laparotomy. Injury. 2010;41(1):64-8.

50. Kashuk $J \mathrm{~L}$, Moore $\mathrm{EE}$, Johnson $J$, et al. Postinjury life threatening coagulopathy: is 1:1 fresh frozen plasma:packed red blood cells the answer? J Trauma. 2008:65(2):261-70.

51. MacKenzie S, Kortbeek JB, Mulloy R, et al. Recent experiences with a multidisciplinary approach to complex hepatic trauma. Injury. 2004;35(9): 869-77.
52. Asensio JA, Petrone P, Roldan G, et al. Has evolution in awareness of guidelines for institution of damage control improved outcome in the management of the posttraumatic open abdomen? Arch Surg. 2004;139(2): 209-14 discussion 15

53. Aucar JA, Norman P, Whitten E, et al. Intraoperative detection of traumatic coagulopathy using the activated coagulation time. Shock. 2003;19(5):404-7.

54. Asensio JA, Petrone P, Roldan $\mathrm{G}$, et al. Analysis of 185 iliac vessel injuries: risk factors and predictors of outcome. Arch Surg. 2003;138(11):1187-93 discussion 93-4.

55. Hirshberg A, Wall MJ Jr, Mattox KL. Bullet trajectory predicts the need for damage control: an artificial neural network model. J Trauma. 2002;52(5): 852-8.

56. Asensio JA, McDuffie $L$, Petrone $P$, et al. Reliable variables in the exsanguinated patient which indicate damage control and predict outcome. Am J Surg. 2001;182(6):743-51.

57. Krishna G, Sleigh JW, Rahman H. Physiological predictors of death in exsanguinating trauma patients undergoing conventional trauma surgery. Aust N Z J Surg. 1998:68(12):826-9.

58. Carrillo EH, Spain DA, Wilson MA, et al. Alternatives in the management of penetrating injuries to the iliac vessels. J Trauma. 1998:44(6):1024-9 discussion 29-30.

59. Cushman JG, Feliciano DV, Renz BM, et al. Iliac vessel injury: operative physiology related to outcome. J Trauma. 1997;42(6):1033-40.

60. Cosgriff N, Moore EE, Sauaia A, et al. Predicting life-threatening coagulopathy in the massively transfused trauma patient: hypothermia and acidoses revisited. J Trauma. 1997;42(5):857-61 discussion 61-2.

61. Garrison JR, Richardson JD, Hilakos AS, et al. Predicting the need to pack early for severe intra-abdominal hemorrhage. J Trauma. 1996;40(6):923-7 discussion 27-9.

62. Rotondo MF, Schwab CW, McGonigal MD, et al. 'Damage control': an approach for improved survival in exsanguinating penetrating abdominal injury. J Trauma. 1993;35(3):375-82 discussion 82-3.

63. Sharp KW, Locicero RJ. Abdominal packing for surgically uncontrollable hemorrhage. Ann Surg. 1992;215(5):467-74 discussion 74-5

64. Rutherford EJ, Morris JA Jr, Reed GW, et al. Base deficit stratifies mortality and determines therapy. J Trauma. 1992;33(3):417-23.

65. Burch JM, Ortiz VB, Richardson RJ, et al. Abbreviated laparotomy and planned reoperation for critically injured patients. Ann Surg. 1992;215(5): 476-83 discussion 83-4.

66. Cue Jl, Cryer HG, Miller FB, et al. Packing and planned reexploration for hepatic and retroperitoneal hemorrhage: critical refinements of a useful technique. J Trauma. 1990;30(8):1007-11 discussion 11-3.

67. Carmona RH, Peck DZ, Lim RC Jr. The role of packing and planned reoperation in severe hepatic trauma. J Trauma. 1984:24(9):779-84.

68. Stone HH, Strom PR, Mullins RJ. Management of the major coagulopathy with onset during laparotomy. Ann Surg. 1983;197(5):532-5.

69. MacLean AA, O'Keeffe T, Augenstein J. Management strategies for the open abdomen: survey of the American Association for the Surgery of Trauma membership. Acta chirurgica Belgica. 2008;108(2):212-8.

70. Kirkpatrick AW, Laupland KB, Karmali S, et al. Spill your guts! Perceptions of Trauma Association of Canada member surgeons regarding the open abdomen and the abdominal compartment syndrome. J Trauma. 2006; 60(2):279-86

71. Karmali S, Evans D, Laupland KB, et al. To close or not to close, that is one of the questions? Perceptions of Trauma Association of Canada surgical members on the management of the open abdomen. J Trauma. 2006;60(2): 287-93.

72. Mayberry JC, Goldman RK, Mullins RJ, et al. Surveyed opinion of American trauma surgeons on the prevention of the abdominal compartment syndrome. J Trauma. 1999;47(3):509-13 discussion 13-4.

73. Sox HC, Goodman SN. The methods of comparative effectiveness research. Ann Rev Public Health. 2012;33:425-45.

74. Kirkpatrick AW, Roberts DJ, De Waele J, et al. Intra-abdominal hypertension and the abdominal compartment syndrome: updated consensus definitions and clinical practice guidelines from the World Society of the Abdominal Compartment Syndrome. Intensive Care Med. 2013:39(7):1190-206.

75. Balogh ZJ, Lumsdaine W, Moore EE, et al. Postinjury abdominal compartment syndrome: from recognition to prevention. Lancet. 2014; 384(9952):1466-75. 
76. Roberts DJ, Ball CG, Kirkpatrick AW. Increased pressure within the abdominal compartment: intra-abdominal hypertension and the abdominal compartment syndrome. Curr Opin Crit Care. 2016;22(2): 174-85.

77. Schreiber MA. The beginning of the end for damage control surgery. Br J Surg. 2012;99(Suppl 1):10-1.

\section{Publisher's Note}

Springer Nature remains neutral with regard to jurisdictional claims in published maps and institutional affiliations.

- fast, convenient online submission

- thorough peer review by experienced researchers in your field

- rapid publication on acceptance

- support for research data, including large and complex data types

- gold Open Access which fosters wider collaboration and increased citations

- maximum visibility for your research: over $100 \mathrm{M}$ website views per year

At $\mathrm{BMC}$, research is always in progress. 